\title{
Prediction of Transporter-Mediated Drug-Drug Interactions and Phenotyping of Hepatobiliary Transporters Involved in the Clearance of E7766, a Novel Macrocycle-Bridged Dinucleotide ${ }^{\mathbb{\Phi}}$
}

\author{
Rongrong Jiang, Andrew Hart, ${ }^{1}$ Laurette Burgess, Dae-Shik Kim, @Weidong George Lai, ${ }^{2}$ \\ and $\odot$ Vaishali Dixit ${ }^{3}$
}

Drug Metabolism and Pharmacokinetics (R.J., V.D., W.G.L., A.H.) and Genetics Guided Dementia Discovery, Eisai Inc, Cambridge, Massachusetts (L.B., D.-S.K.)

Received May 20, 2020; accepted December 10, 2020

\begin{abstract}
E7766 represents a novel class of macrocycle-bridged dinucleotides and is under clinical development for immuno-oncology. In this report, we identified mechanism of systemic clearance E7766 and investigated the hepatobiliary transporters involved in the disposition of E7766 and potential drug interactions of E7766 as a victim of organic anion-transporting polypeptide (OATP) inhibitors. In bileduct cannulated rats and dogs, E7766 was mainly excreted unchanged in bile $(>80 \%)$ and to a lesser extent in urine $(<20 \%)$. Sandwich-cultured human hepatocytes (SCHHs), transfected cells, and vesicles were used to phenotype the hepatobiliary transporters involved in the clearance of E7766. SCHH data showed temperaturedependent uptake of E7766 followed by active biliary secretion. In vitro transport assays using transfected cells and membrane vesicles confirmed that E7766 was a substrate of OATP1B1, OATP1B3, and multidrug resistance-associated protein 2. Phenotyping studies suggested predominant contribution of OATP1B3 over OATP1B1 in the hepatic uptake of E7766. Studies in OATP1B1/1B3 humanized mice showed that plasma exposure of E7766 increased 4.5fold when coadministered with Rifampicin. Physiologically based
\end{abstract}

Introduction

Stimulator of interferon genes (STING) is an important innate immune sensor, and activation of STING plays a critical role in

\footnotetext{
${ }^{1}$ Current affiliation: Wave Life Sciences, Lexington, Massachusetts.

${ }^{2}$ Current affiliation: Triplet Therapeutics, Cambridge, Massachusetts.

${ }^{3}$ Current affiliation: Kymera Therapeutics, Watertown, Massachusetts.

https://doi.org/10.1124/dmd.120.000125.
}

SThis article has supplemental material available at dmd.aspetjournals.org. pharmacokinetic models built upon two independent bottom-up approaches predicted elevation of E7766 plasma exposure when administered with Rifampicin, a clinical OATP inhibitor. In conclusion, we demonstrate that OATP-mediated hepatic uptake is the major contributor to the clearance of E7766, and inhibition of OATP1B may increase its systemic exposure. Predominant contribution of OATP1B3 in the hepatic uptake of E7766 was observed, suggesting polymorphisms in OATP1B1 would be unlikely to cause variability in the exposure of E7766.

\section{SIGNIFICANCE STATEMENT}

Understanding the clearance mechanisms of new chemical entities is critical to predicting human pharmacokinetics and drug interactions. A physiologically based pharmacokinetic model that incorporated parameters from mechanistic in vitro and in vivo experiments was used to predict pharmacokinetics and drug interactions of E7766, a novel dinucleotide drug. The findings highlighted here may shed a light on the pharmacokinetic profile and transportermediated drug interaction propensity of other dinucleotide drugs.

ABBREVIATIONS: $A_{e}$ fecal, amount excreted in feces; $A_{e}$ biliary, amount excreted in bile; $A_{e}$ renal, amount excreted in urine; $A U C$, area under the curve; $\mathrm{AUC}_{\text {total }}$, area under the total plasma concentration-time curve; BCRP, breast cancer resistance protein; BDC, bile-duct cannulated; BEI, biliary excretion index; BSEP, bile salt export pump; $C L$, clearance; $\mathrm{CL}_{\text {biliary }}$, hepatobiliary excretory clearance; $\mathrm{CL}_{\text {fecal }}$, fecal excretory clearance;

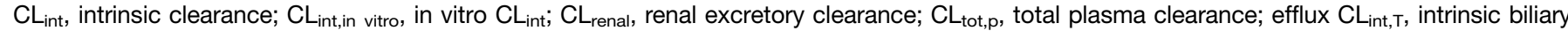
efflux clearance; DDI, drug-drug interaction; d8-TCA, deuterium-labeled sodium taurocholate; $f_{\mathrm{t}}$, fraction transported by individual transporter; HEK, human embryonic kidney; IS, internal standard; $J_{\max }$, in vitro maximum rate of transporter mediate uptake or efflux; KH, Krebs-Henseleit; $K_{\mathrm{m}}$, Michaelis-Menten constant; $K_{\mathrm{p}}$, tissue-to-plasma partition coefficient; LC-MS/MS, liquid chromatography tandem mass spectrometry; liver

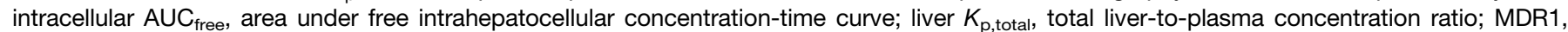
multidrug resistance 1; MRP, multidrug resistance-associated protein; NCE, new chemical entity; NTCP, $\mathrm{Na}^{+} /$taurocholate-cotransporting polypeptide; OAT, organic anion transporter; OATP, organic anion-transporting polypeptide; PBPK, physiologically based PK; PK, pharmacokinetic; REF, relative expression factor; SCHH, sandwich-cultured human hepatocyte; SLC, solute carrier; STING, stimulator of interferon genes; uptake $\mathrm{CL}_{\text {int, } \mathrm{T}}$, intrinsic hepatic uptake clearance; $V_{\mathrm{ss}}$, distribution volume at steady state; $\mathrm{WT}$, wild type; $\mathrm{Xb}_{(0-\mathrm{t})}$, cumulative amount of compound recovered in bile; $\mathrm{Xf}_{(0-\mathrm{t})}$, cumulative amount of compound recovered in feces; $\mathrm{Xu}_{(0-\mathrm{t})}$, cumulative amount of compound recovered in urine. 
dinucleotides were generally characterized by moderate-to-high molecular weight $(>400)$, low $\log \mathrm{P}(<1)$, and pKa of 3 to 4 . Macrocyclebridged dinucleotides also have low permeability and as such fall in the class 3B of the extended clearance classification system (ECCS) (Varma et al., 2015), thus making them potential substrates for hepatic uptake and efflux transporters. Many compounds in this series showed high clearance that was at or exceeded hepatic blood flow and had low volume of distribution. Additionally, the compounds were metabolically stable in rodent and human hepatocytes and liver S9 fraction, indicating that metabolism was unlikely to be the primary clearance pathway. Identifying clearance mechanisms of these novel class compounds in drug discovery is important to predict systemic and target tissue exposure as well as to predict clinical drug-drug interaction (DDI).

The significant clinical implications of inhibiting hepatic uptake transporters, such as organic anion-transporting polypeptide (OATP) $1 \mathrm{~B}$, have highlighted the importance of assessing this potential liability for new chemical entities (NCEs) during drug discovery and development (Chen et al., 2018). The US Food and Drug Administration and the European Medicines Agency (EMA) have also issued guidance for the in vitro and in vivo evaluation of the transporter-based DDI (European Medicines Agency, 2012, US Food and Drug Administration, 2017). Predicting DDI for substrates of OATP1B1 and OAPT1B3 has recently been described in many reports (Duan et al., 2017; Yoshikado et al., 2018). Physiologically based pharmacokinetic (PBPK) modeling has been recognized to be a powerful tool for pharmacokinetic (PK) and DDI predictions of substrates of hepatic uptake transporters as well as drug-metabolizing enzymes (Jones et al., 2015; Wang et al., 2017). In addition to predicting DDI, PBPK can also be used in the mechanistic understanding of various rate-limiting and rate-determining processes in the disposition of drugs.

E7766 was selected as a suitable model compound for investigating the clearance mechanisms and transporter-mediated DDI propensity of macrocycle-bridged dinucleotide-type STING agonists. A series of nonclinical studies was planned and conducted to 1) assess the major clearance mechanisms in the systemic clearance of E7766, 2 ) identify the transporters and estimate their relative contributions to the hepatic clearance of E7766, and 3) use the in vitro transporter data and PBPK model framework to prospectively predict the clinical DDI of E7766 with OATP1B inhibitor. To best of our knowledge, this is the first report for the identification of hepatobiliary transporters and PBPK modeling-based DDI prediction of therapeutically important and structurally novel macrocycle-bridged dinucleotides. Our data underscore the importance of OATP1B, especially OATP1B3, in determining the systemic hepatic clearance rate and hence the plasma exposure of E7766 and perhaps this class of compounds. Furthermore, our results also show that clinically relevant DDIs leading to changes in plasma exposure can occur if E7766 is coadministered with OATP1B3 inhibitors. The predominant contribution of OATP1B3 to the clearance of E7766 suggests that the plasma exposure to E7766 is less likely to be subjected to interindividual variability due to polymorphisms in OATP1B1.

\section{Materials and Methods}

Chemicals and Reagents. E7766 and the internal standard (IS) ER001229535 (Lot ER-001229535-NH4-011) were synthesized at Eisai Inc. (Andover, MA). Bovine serum albumin solution was purchased from American Tissue Culture Collection (Manassas, VA). Estradiol-17 $\beta$-glucuronide $\left(\mathrm{E}_{2} 17 \beta \mathrm{G}\right)$, Rifampicin, and Krebs-Henseleit $(\mathrm{KH})$ buffer were purchased from SigmaAldrich (St. Louis, MO). Porcine kidney LLC-PK1 parental cells were obtained

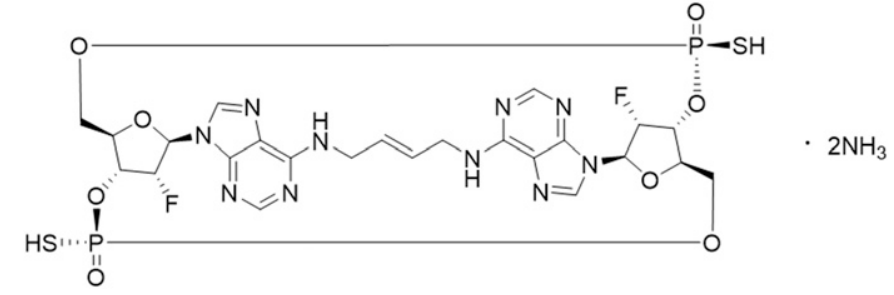

Fig. 1. Structure of E7766, a novel agonist of STING pathway.

from Discovery Labware, Inc (now Corning Inc., Tewkbury, MA). Human embryonic kidney (HEK) 293FT cells stably transfected with the vector containing OATP1B1 cDNA or OATP1B3 cDNA or empty vector were obtained from Solvo Biotechnology (Zeged, Hungary). TransportoCells transiently transfected with the vector containing OATP2B1 cDNA or NTCP cDNA or empty vector were purchased from Corning (NY). The cell culture-related reagents were cell culture-grade and were purchased from Thermo Scientific, Inc. (Herndon, VA). All other reagents used in this study were of either analytical or high-performance liquid chromatography grade.

Transport Studies of E7766 with Hepatic Solute Carrier Transporters. TransportoCells (Corning) transiently expressing OATP2B1 or NTCP and the control cells (HEK293 cells transfected with empty vector) and HEK293FT cell line (Solvo Biotechnology) stably expressing OATP1B1 (HEK293FTOATP1B1) or OATP1B3 (HEK293FT-OATP1B3) and the control cells (HEK293FT-control; HEK293FT cells transfected with empty vector) were grown in a Dulbecco's modified Eagle's medium fortified with $10 \%$ fetal calf serum and $2 \mathrm{mmol} / \mathrm{L}$ sodium butyrate (for NTCP only) in a humidified incubator at $37^{\circ} \mathrm{C}$ and $5 \% \mathrm{CO}_{2}$. Solvo HEK293FT cells were harvested at $90 \%$ confluence and then seeded in poly-D-lysine-coated 24-well 24 hours prior to transporter assay, whereas Corning TransportoCells were thawed and seeded in poly-D-lysine-coated 96 -well 24 hours prior to transporter assay. Cellular transport assays were conducted as described previously (Jiang et al., 2015). Briefly, cells were washed twice and preincubated with $200 \mu \mathrm{l}$ of prewarmed KH buffer. After preincubation, cells were incubated with 3 or $10 \mu \mathrm{mol} / 1$ of E7766 in presence or absence of $100 \mu \mathrm{mol} / 1$ of inhibitors (Rifamycin SV for OATP2B1, Troglitazone for NTCP, and Rifampicin for OATP1B1 and OATP1B3). The transport reaction was terminated by aspirating the buffer from the wells at designated time. After washing three times with $200 \mu \mathrm{l}$ of ice-cold KH buffer, the cells were lysed, and the resulting cellular lysates were analyzed by liquid chromatography tandem mass spectrometry (LC-MS/MS).

The time-dependent uptake of E7766 with OATP1B1 and OATP1B3 was evaluated to confirm linear uptake condition range of uptake of E7766 (Supplemental Fig. 2). Concentration-dependent uptake of E7766 via OATP1B1 and OATP1B3 was examined with a concentration range of $0.25-100 \mu \mathrm{mol} / \mathrm{l}$ under linear conditions at 5 minutes. All experiments were run in triplicate.

Transport Studies of E7766 with Hepatic ATP-Binding Cassette Transporters. TransportoCells membrane vesicles (Corning) expressing MDR1, BCRP, BSEP, or MRP2 and control vector vesicles $(70 \mu \mathrm{l})$ were preincubated with vesicle uptake buffer $(47 \mathrm{mmol} / 1$ 4-morpholinepropanesulfonic acid/Tris, $65 \mathrm{mmol} / \mathrm{l} \mathrm{KCl}, 7 \mathrm{mmol} / \mathrm{l} \mathrm{MgCl} 2$, pH 7.4 for MDR1 and BCRP; $47 \mathrm{mmol} / \mathrm{l}$ 4-morpholinepropanesulfonic acid/Tris, $2.5 \mathrm{mmol} / \mathrm{l}$ glutathione, $65 \mathrm{mmol} / \mathrm{l} \mathrm{KCl}$, $7 \mathrm{mmol} / 1 \mathrm{MgCl}_{2}, \mathrm{pH} 7.4$ for MRP2; and $10 \mathrm{mmol} / \mathrm{l} \mathrm{HEPES}$-Tris, $100 \mathrm{mmol} / \mathrm{l}$ $\mathrm{KNO}_{3}, 12.5 \mathrm{mmol} / \mathrm{l} \mathrm{Mg}\left(\mathrm{NO}_{3}\right)_{2}$, and $50 \mathrm{mmol} / \mathrm{l}$ sucrose, $\mathrm{pH} 7.4$ for BSEP) at $37^{\circ} \mathrm{C}$ for 10 minutes. The transport was initiated by adding $125 \mu \mathrm{l}$ of prewarmed $25 \mathrm{mmol} / \mathrm{l} \mathrm{MgATP}$ and $3 \mu \mathrm{mol} / \mathrm{l}$ of E7766 in the presence or absence of inhibitors ( $3 \mu \mathrm{mol} / \mathrm{l}$ of Novobioncin for BCRP, $100 \mu \mathrm{mol} / \mathrm{l}$ of MK-571 for MRP2, and $20 \mu \mathrm{mol} / \mathrm{l}$ of Ketoconazole for MDR1 and BSEP). The transport was terminated at designated time by adding $200 \mu \mathrm{l}$ ice-cold vesicle uptake buffer. The complete content was then rapidly filtrated using multiscreen HTS vacuum manifold, which was followed by five washes and filtrations. The plate was allowed to dry completely and then placed onto a 96-well receiver plate. An amount $(50 \mu \mathrm{l})$ of elute solution (75\% methanol containing the internal standard) was added into each assay well, and this was followed by centrifugation at $2000 \mathrm{rpm}$ for 5 minutes. This lysis-and-centrifugation procedure was repeated one more time to 
maximize compound extraction. The samples from two centrifugations were combined and analyzed by LC-MS/MS. All experiments were run in triplicate.

The LLC-PK1 cell-based permeability of E7766 was also assessed. Porcine kidney LLC-PK1 cells were cultured at $37^{\circ} \mathrm{C}$ and $5 \% \mathrm{CO}_{2}$ in Medium 199 containing 10\% FBS, $292 \mu \mathrm{g} / \mathrm{ml}$ glutamine, $0.1 \mathrm{mg} / \mathrm{ml}$ hygromycin B, and $0.05 \mathrm{mg} / \mathrm{ml}$ gentamycin. The cells were seeded in HTS Transwell-96 systems (polystyrene, $4.26 \mathrm{~mm}$ in diameter, $0.14 \mathrm{~cm}^{2}$ in surface area, $1.0 \mu \mathrm{m}$ in pore size, Corning Inc.) at a density of approximately $1.4 \times 10^{6}$ cells $/ \mathrm{ml}$. Culture medium was replaced on the 4th and 6th day after seeding. Cells were cultured for 7 days on Transwell plates for the studies. Prior to the experiments, LLC-PK1 cells were washed using transport buffer (Hank's balanced salt solution supplemented with $10 \mathrm{mmol} / \mathrm{l} \mathrm{HEPES}$ ) and incubated for 60 minutes. For the experiments of apical to basolateral direction, transport buffer containing $1 \mu \mathrm{mol} / \mathrm{l}$ of E7766 was added into the apical compartment, whereas transport buffer with the same treatment was added into the basolateral compartment. For the experiments of basolateral to apical direction, transport buffer containing $1 \mu \mathrm{mol} / \mathrm{l}$ of E7766 was added into the basolateral compartment, whereas transport buffer with the same treatment was added into the apical compartment. The length of incubation for transport was 2 hours, and samples were stored at $-70^{\circ} \mathrm{C}$ or lower prior to LC-MS/MS analysis.

Hepatic Uptake and Biliary Excretion of E7766 in Sandwich-Cultured Human Hepatocytes. Transporter-certified cryopreserved human hepatocytes (Donor JEL; BioIVT, Durham, NC) were thawed following manufacturer's instructions. Cryopreserved hepatocytes were subsequently suspended in BioIVT proprietary hepatocyte seeding medium (QualGro Seeding Medium) and seeded at a density of 0.9 million viable cells $/ \mathrm{ml}$ onto BioCoat 24 -well cell culture plates (San Jose, CA). After plating, cells were allowed to attach for 2-4 hours and then were rinsed and fed with warm $\left(37^{\circ} \mathrm{C}\right)$ seeding medium. Eighteen to 24 hours later, cells were fed and overlaid with QualGro culture medium (QTS, Durham, NC) supplemented with extracellular matrix Matrigel $\left(0.25 \mathrm{mg} \cdot \mathrm{ml}^{-1}\right.$; BD Biosciences, San Jose, CA). Cells were then maintained in QualGro Hepatocyte Culture Medium. Hepatic uptake clearance and hepatobiliary disposition of test articles were assessed on day 5 by using B-CLEAR Technology (Swift et al., 2010). Briefly, to assess uptake clearance, cell culture medium was removed, and hepatocytes were washed three times with warm Plus $(+)$ buffer $(0.3 \mathrm{ml}$ per well). Immediately after washing step, dose solutions for E7766 or comparators $(0.3 \mathrm{ml}$ per well) were added and incubated for 1,5 , and 10 minutes at $37^{\circ} \mathrm{C}$. After incubation period, the solutions were collected and frozen at $-80^{\circ} \mathrm{C}$ until process for bioanalysis. The wells were then washed three times with ice-cold Plus $(+)$ buffer. The plates were frozen at $-80^{\circ} \mathrm{C}$ until bioanalysis.

To assess biliary clearance, cell culture medium was removed, and hepatocytes were washed twice with warm Plus (+) or Minus (-) buffer to maintain or disrupt tight junctions, respectively. The wash solutions were removed and replaced with fresh Plus (+) buffer or Minus ( - ) buffer $(0.3 \mathrm{ml}$ per well). The hepatocytes were conditioned for 10 minutes at $37^{\circ} \mathrm{C}$. The conditioning solutions were removed and replaced with dosing solutions for E7766 or comparators $(0.3 \mathrm{ml}$ per well). After a 20-minute incubation, the solutions were collected and frozen at $-80^{\circ} \mathrm{C}$ until process for bioanalysis. The wells were then washed three times with ice-cold Plus (+) buffer. The plates were frozen at $-80^{\circ} \mathrm{C}$ until process for bioanalysis. All experiments were run in triplicate.

In Vivo Pharmacokinetics. All in vivo study protocols were approved by appropriate Institutional Animal Care and Use Committee. Animals were monitored during the study and provided free access to food and water.

Pharmacokinetics in Bile-Duct Cannulated Rats and Dogs. Bile-duct cannulated (BDC) male Sprague-Dawley rats $(n=4)$ and BDC male Beagle dogs $(n=3)$ were given E7766 as a single $1-\mathrm{mg} / \mathrm{kg}$ i.v. dose and $0.075-\mathrm{mg} / \mathrm{kg}$ i.v. dose as free acid prepared in sterile PBS, respectively. Plasma samples were collected at predose and designated time points postdose via a jugular vein into tubes containing sodium heparin as the anticoagulant. Urine samples were collected at intervals $0-4,4-8$, and 8-24 hours postdose into collection tubes on wet ice. Bile and feces (rat-only) samples were collected at intervals 0-4, 4-8, and 8-24 hours postdose into collection tubes on wet ice. All samples were stored at $-70^{\circ} \mathrm{C}$ or lower until LC-MS/MS analysis.

Pharmacokinetics in Humanized OATP1B1/1B3 and Wild-Type Mice. E7766 was formulated in $0.5 \% 0.1 \mathrm{~N} \mathrm{HCl}, 5 \% \mathrm{DMSO}, 10 \% \mathrm{EtOH}$, and $84.5 \%$ saline for studies in wild-type (WT) and humanized OATP1B1/1B3 mice. Rifampicin was formulated in $0.5 \% 0.1 \mathrm{~N} \mathrm{HCl}, 5 \% \mathrm{DMSO}, 10 \% \mathrm{EtOH}$, and $84.5 \%$ saline. Age-matched OATP1B1 and OATP1B3-knock-in humanized mice $(n=3)$ on the Oatpla/1b-knockout background and WT FVB male mice
( $n=3 /$ time point) were purchased from Taconic Biosciences (Hudson, NY). Mice were between 8 and 10 weeks of age (22-34 g) at the time of study. In WT mice, E7766 was administered via the tail vein at a dose of $0.5 \mathrm{mg} / \mathrm{kg}$ with either vehicle or Rifampicin (30 mg/kg i.v.). Plasma and liver samples were collected at 0.083 , $0.25,0.5,1,1.5,3$, and 6 hours, and all samples were stored at $-80^{\circ} \mathrm{C}$ until bioanalysis. In humanized mice, E7766 was administered via the tail vein at a dose of $1 \mathrm{mg} / \mathrm{kg}$ or together with vehicle or with Rifampicin $(\mathrm{E} 7766,0.5 \mathrm{mg} / \mathrm{kg}$; Rifampicin, $10 \mathrm{mg} / \mathrm{kg}$ ). Blood samples were collected at predose and 0.08, 0.25, $0.51,1.5,3,6$, and 24 hours postdose via saphenous or tail vein into a heparinized capillary. The contents of the capillary were expelled onto an appropriate spot on a dry blood spot card (FTA DMPK-B [GE Healthcare, Life Sciences, Whatman]). Urine and feces samples were collected from all dose groups at intervals 0-8 and 8-24 hours postdose. Samples were stored at $-80^{\circ} \mathrm{C}$ until bioanalysis.

LC-MS/MS Analysis. Cell lysate samples were extracted by 70:30 methanol: water (v:v) containing IS $10 \mathrm{nmol} / \mathrm{L}$ ER-001229535. Plasma samples were subjected to protein precipitation with methanol containing ER-001229535 as the IS. Urine, bile, and feces samples were extracted via salting-out-assisted liquidliquid extraction based on the methodologies described by Tang and Weng (2013). For analysis of E7766 and IS of ER-001229535, a Shimadzu highperformance liquid chromatography system (Shimadzu Scientific Instruments, Columbia, MD), which consisted of an autosampler (model: SIL HTc), a column compartment unit (model: CTO-20AC), a degasser (model: DGU-20A3), two pumps (model: LC-20AD), and a high-pressure switching valve (model: FCV20AH6), was used. The mobile phase A consisted of $2 \mathrm{mmol} / \mathrm{l}$ ammonium bicarbonate in $\mathrm{H}_{2} \mathrm{O} / \mathrm{MeOH}(95 / 5$, v/v), and mobile phase B consisted of $2 \mathrm{mmol} / \mathrm{l}$ ammonium bicarbonate in $\mathrm{MeOH} / \mathrm{H}_{2} \mathrm{O}(95 / 5, \mathrm{v} / \mathrm{v})$. Aliquots $(10 \mu \mathrm{l})$ were injected onto a Waters XBridge Oligonucleotide BEH C18 column, $130 \AA$, $2.5 \mu \mathrm{m}$ ( $4.6 \mathrm{~mm}$ inner diameter $\times 50 \mathrm{~mm}$ length), at a flow rate of $0.5 \mathrm{ml} / \mathrm{min}$ at $40^{\circ} \mathrm{C}$. The temperature of the autosampler was controlled at $4^{\circ} \mathrm{C}$. The samples were analyzed on an API5000 (Sciex, Framingham, MA) triple quadrupole mass spectrometer with turbospray ionization (ESI) under negative ion mode. A 9-minute gradient was run for E7766 and IS, with a flow rate of $0.5 \mathrm{ml} / \mathrm{min}$ as follows: $0 \% \mathrm{~B}$ for 0.3 minutes, $0 \%-100 \%$ B over 2.7 minutes, $100 \%$ B for 2 minutes, $100 \%-0 \%$ B over 0.2 minutes, and then re-equilibration at $0 \% \mathrm{~B}$ for 3.8 minutes. Analytes were detected by multiple reaction monitoring by the following mass transitions: 372.4 $(\mathrm{M}-2 \mathrm{H})^{2-}>186.5$ for E7766 $(-38 \mathrm{eV}$ collisions $)$ and $689.3(\mathrm{M}-\mathrm{H})^{-}>134.1$ for IS ( $-75 \mathrm{eV}$ collisions).

PBPK Model and DDI Simulations. Whole-body PBPK modeling and simulation were performed using the population-based absorption, distribution, metabolism, and excretion simulator, SimCYP (version 18; Certara, Sheffield, UK). Each simulation was performed for 100 subjects (10 trials $\times 10$ subjects $)$ using the software's built-in healthy volunteer virtual population. To simulate the effect of OATP inhibitors on the PK of E7766, the PBPK model for RifampicinSD was adopted directly from the default SimCYP compound library. For all simulations, E7766 was administered as a single intravenous dose, and Rifampicin was administered as a single oral dose. Physicochemical properties and input parameters for E7766 used for the PBPK model are summarized in Table 4. Parameters of Rifampicin for the DDI simulation are summarized in Supplemental Table 4

The full PBPK model with method 2 (based on Rodgers and Rowland) was used to predict the volume of distribution $\left(V_{\mathrm{d}}\right)$ of E7766 (Rodgers et al., 2005; Rodgers and Rowland, 2006). A $K_{\mathrm{p}}$ scalar of 4 was applied to the prediction of human $\mathrm{V}_{\mathrm{d}}$. The $K_{\mathrm{p}}$ scalar was determined based on the predicted versus observed $V_{\mathrm{d}}$ of E7766 in preclinical species. Permeability-limited disposition was considered for liver. The DDI simulation was run in two scenarios: 1) hepatic uptake clearance was assigned from the transporter kinetics $\left(V_{\max } / K_{\mathrm{m}}\right)$ for OATP1B1 and OATP1B3 measured in the HEK293FT system and intrinsic passive diffusion across the sinusoidal membrane measured in sandwich-cultured human hepatocyte $(\mathrm{SCHH})$ studies and 2) intrinsic active uptake clearance, passive clearance on the sinusoidal membrane, and efflux clearance on the canalicular membrane measured in the SCHH studies were used to capture hepatobiliary disposition. In both scenarios, the intrinsic uptake clearances were scaled up to physiologically relevant uptake clearance by a relative expression factor (REF) approach (Hirano et al., 2004) within SimCYP models. Additionally, in second scenario, the intrinsic uptake clearance from $\mathrm{SCHH}$ was assigned to OATP1B3 $\left(f_{\mathrm{t}}=0.97\right)$ to capture the DDI. Based on in vitro metabolism data using cryopreserved human hepatocytes (unpublished data), metabolic clearance was assumed to be negligible for both simulations. PK in preclinical studies suggests 
that E7766 is expected to be eliminated from kidney via glomerular filtration. The renal clearance of E7766 was then fixed as $3 \mathrm{~L} / \mathrm{h}$ as a product of glomerular filtration rate ( $\sim 61 / \mathrm{h}$ in human; Lin et al., 2003) and plasma protein binding of E7766 (0.5, measured data, Table 4). This fixed renal clearance also aligned well with back calculation from systemic clearance and the observation from PK studies of multiple preclinical species, in which about $10 \%$ of E7766 was excreted in urine as parent compound. Sensitivity analysis was performed to evaluate changes in drug exposure and DDI due to any uncertainty in the in vitro parameters.

Data Analysis. The uptake velocity describes the rate of E7766 taken up by active and/or passive processes of the transporter-expressing cell or vesicles and is calculated as follows:

$$
\text { uptake velocity }=(C \times V) / T / W
$$

wherein $C$ represents the concentration of E7766 in the cellular (or vesicular) lysate (micromole per liter), $V$ is the volume of the lysate (microliter), $\mathrm{T}$ is the incubation time, and $\mathrm{W}$ is the measured cellular (or vesicular) protein amount of each well (milligram).

The OATP1B1- or OATP1B3-specific uptake velocity was calculated by subtracting mean uptake velocity of E7766 in HEK293-control cells from that of HEK293FT-OATP1B1 or HEK293FT-OATP1B3 cells at each of the corresponding concentration. Kinetic and statistical analyses of the transport data were conducted using GraphPad Prism Ver. 7.02 (GraphPad Software, Inc., San Diego, CA). Kinetic data were fit to a Michaelis-Menten model as follows:

$$
v=V_{\max } \times S /\left[K_{\mathrm{m}}+S\right]
$$

wherein $v$ is the OATP1B1- or OATP1B3-specific uptake velocity (pmol/m1/mg protein), $S$ is the concentration of E7766 in the uptake buffer (micromoles per liter), $K_{\mathrm{m}}$ is the apparent Michaelis-Menten constant (micromoles per liter), and $V_{\max }$ is the apparent maximum uptake rate (picomoles per minute per milligram protein). The in vitro intrinsic clearance $\left(\mathrm{CL}_{\text {int, in vitro }}\right)$ was calculated as follows:

$$
\mathrm{CL}_{\text {int,in vitro }}=\mathrm{V}_{\max } / K_{m}
$$

The relative contribution of OATP1B1 and OATP1B3 to the hepatic uptake of E7766 was assessed by the REF approach (Kunze et al., 2014). REF for each transporter was calculated by following equations:

$$
\begin{aligned}
\mathrm{REF}_{1 \mathrm{~B} 1} & =\mathrm{EXP}_{\mathrm{OATP1B} 1, \mathrm{HEP}} / \mathrm{EXP}_{\mathrm{OATP1B} 1, \mathrm{HEK}} \\
\mathrm{REF}_{1 \mathrm{~B} 3} & =\mathrm{EXP}_{\mathrm{OATP} 1 \mathrm{~B} 3, \mathrm{HEP}} / \mathrm{EXP}_{\mathrm{OATP1B} 3, \mathrm{HEK}}
\end{aligned}
$$

wherein EXP represents the specific transporter expression (femtomoles per milligram protein) determined in primary human hepatocyte (HEP) or HEK293FT-OATP1B1 or HEK293FT-OATP1B3 cell line (HEK). The expression levels of OAPT1B1 and OATP1B3 in hepatocyte and HEK293FToverexpressing cell line are summarized in Supplemental Table 2.

For $\mathrm{SCHH}$ assays, the intrinsic hepatic uptake clearance (uptake $\mathrm{CL}_{\mathrm{int}, \mathrm{T}}$ ) was determined using the following:

$$
\text { Uptake } \mathrm{CL}_{\text {int }, \mathrm{T}}=A_{\text {Plus }(+) \text { Buffer }} /\left(T \times C_{\text {initial }}\right)
$$

wherein $A_{\text {Plus (+)Buffer }}$ is the total accumulation of E7766 (cells + bile pocket) in $\mathrm{SCHH}$ after incubation with Plus (+) buffer (micromoles), $T$ is the incubation time (minutes), and $C_{\text {initial }}$ is the initial concentration of E7766 in dosing medium (micromoles per liter).

The biliary excretion index (BEI) was obtained from eq. 7, and intrinsic biliary clearance (efflux $\mathrm{CL}_{\mathrm{int}, \mathrm{T}}$ ) was calculated from eq. 8:

$$
\begin{gathered}
\mathrm{BEI}=100 \times\left[A_{\text {Plus }(+) \text { Buffer }}-A_{\text {Minus (-)Buffer }}\right] / A_{\text {Plus }(+) \text { Buffer }} \\
\text { Efflux } \mathrm{CL}_{\text {int }, \mathrm{T}}=\left[A_{\text {Plus }(+) \text { Buffer }}-A_{\text {Minus }(-) \text { Buffer }}\right] /\left(T \times C_{\text {initial }}\right)
\end{gathered}
$$

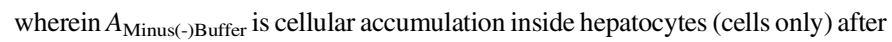
incubation with Minus ( - ) buffer (micromoles).

PK parameters of E7766 were obtained by noncompartmental analysis using Phoenix WinNonlin Ver. 7.0.0.2535 (Certara USA, Inc., Princeton, NJ). The parameters calculated were the cumulative amount of E7766 recovered in urine $\left(\mathrm{Xu}_{(0-\mathrm{t})}\right)$, bile $\left(\mathrm{Xb}_{(0-\mathrm{t})}\right)$, and feces $\left(\mathrm{Xf}_{(0-\mathrm{t})}\right)$, which were determined as the sum of the amounts recovered in each sampling interval; the percent of the administered dose excreted in urine $\left(\mathrm{A}_{\mathrm{e} \text { renal }} \%\right)$, bile $\left(\mathrm{A}_{\mathrm{e} \text { biliary }} \%\right)$, and feces $\left(\mathrm{A}_{\mathrm{e} \text { fecal }} \%\right)$; and the renal $\left(\mathrm{CL}_{\text {renal }}\right)$, biliary $\left(\mathrm{CL}_{\text {biliary }}\right)$, and fecal clearances $\left(\mathrm{CL}_{\text {fecal }}\right)$, which were calculated using the cumulative amount recovered up to the last measurable urine, bile, or feces sample along with the $\mathrm{AUC}_{(0-\mathrm{t}, \text { last })}$ as $\mathrm{CL}_{\text {renal }}=\mathrm{Xu}_{(0-\mathrm{t}, \text { last })} / \mathrm{AUC}_{(0-\mathrm{t}, \text { last })} /$ body weight, $\mathrm{CL}_{\text {biliary }}=\mathrm{Xb}_{(0-\mathrm{t} \text {, last })} / \mathrm{AUC}_{(0-\mathrm{t} \text {, last })} /$ body weight, and $\mathrm{CL}_{\text {fecal }}=\mathrm{Xf}_{(0-\mathrm{t} \text {, last })} /$ $\mathrm{AUC}_{(0-\mathrm{t}, \text { last })} /$ body weight, respectively.

\section{Results}

Assessment of E7766 as a Substrate of Hepatic Uptake Transporters. As shown in Fig. 2A, OATP1B1 and OATP1B3 showed significant active uptake of E7766 $(P<0.000001$ and $P=0.000021$ for OATP1B1 and OATP1B3, respectively), which could be inhibited by Rifampicin $(100 \mu \mathrm{mol} / \mathrm{l} ; P<0.000001$ and $P=0.000007$ for OATP1B1 and OATP1B3, respectively). Active uptake of E7766 was not observed in cells expressing OATP2B1 $(P=0.11)$ or NTCP $(P=0.11)$. The results indicate that E7766 is a substrate for OATP1B1 and OATP1B3 but not a substrate for OATP2B1 and NTCP. We observed differences in passive uptake of E7766 with mock cells groups, and this was at least partially due to the differences in cell subtypes, cell engineering, culture conditions, and assay conditions. Additionally, very low passive permeability of E7766 could add further variability of passive uptake with mock cells. To support the validation of in vitro assay systems, uptake activity of positive control substrates was summarized in Supplemental Fig. 1A.

The results of concentration-dependent uptake of E7766 in HEK293FTOATP1B1, HEK293FT-OATP1B3, and HEK293FT-control cells are

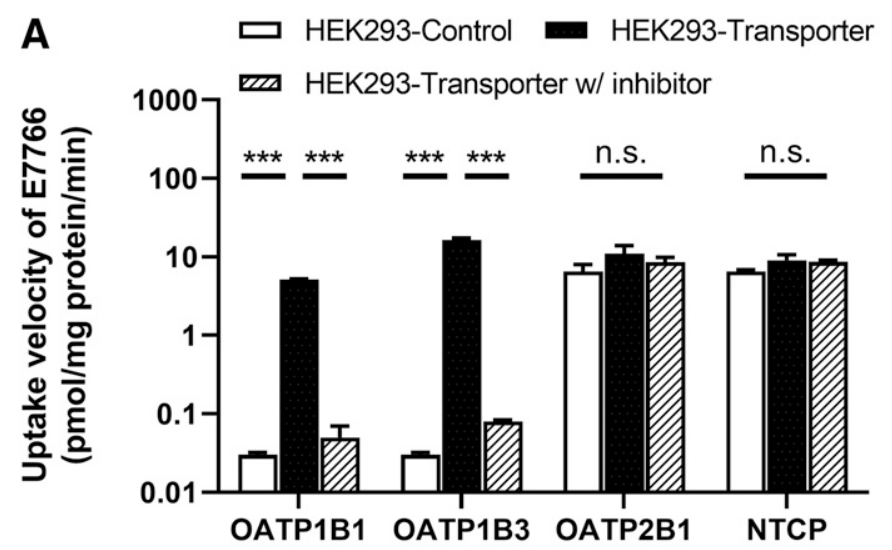

B

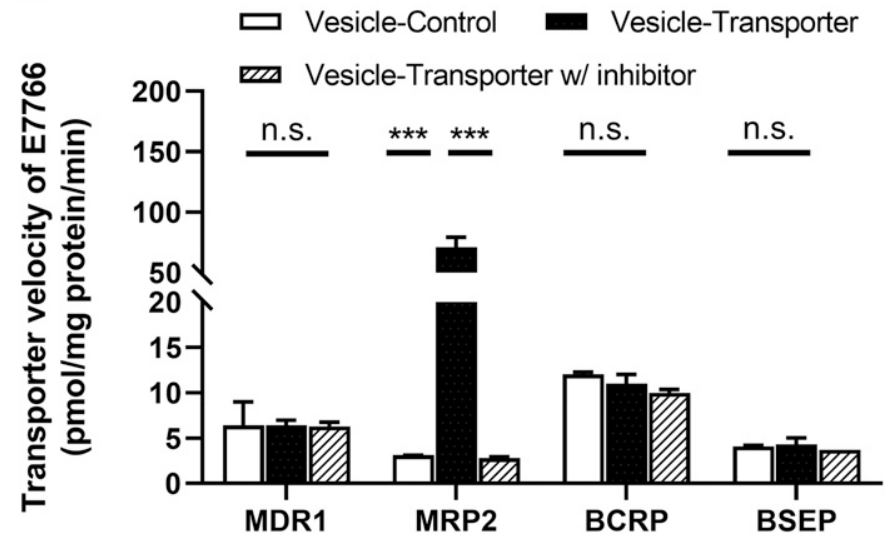

Fig. 2. Phenotyping of hepatobiliary transporters involved in the disposition of E7766. (A) Uptake of E7766 was evaluated in SLC transporter-expressing HEK293 cells; (B) transport of E7766 was evaluated on ATP-binding cassette transporter-expressing membrane vesicles. n.s., not significant. 
summarized in Fig. 3. The data were best-fitted to a Michaelis-Menten model, and the kinetic parameters for uptake of E7766 by OATP1B1 were calculated as $2.2 \mu \mathrm{mol} / \mathrm{l}\left(K_{\mathrm{m}}\right)$ and $27.8 \mathrm{pmol} / \mathrm{min}$ per milligram protein $\left(V_{\max }\right)$. The in vitro uptake clearance $\left(\mathrm{CL}_{\text {int,in vitro }}\right)$ of OATP1B1 was then calculated to be $12.6 \mu \mathrm{l} / \mathrm{min}$ per milligram protein. The $K_{\mathrm{m}}$, $V_{\max }$, and $\mathrm{CL}_{\text {int,in vitro }}$ of OATP1B3-mediated uptake of E7766 were estimated as $4.0 \mu \mathrm{mol} / 1,81.3 \mathrm{pmol} / \mathrm{min}$ per milligram protein, and $20.5 \mu \mathrm{l} / \mathrm{min}$ per milligram protein, respectively. The REFs for OATP1B1 and OATP1B3 were calculated to be 0.1 and 2.8, respectively, using the measured expression of these transporters in the overexpressing cell lines and the reported expression levels in human hepatocytes from Schaefer et al. (2012) (Supplemental Table 2). We decided to use the transporter expression reported by Schaefer et al. (2012) because the methodology used to extract the membrane protein and measure the protein content aligned with the methodology used to measure transporter expression in our HEK293FT-overexpressing system.

Assessment of E7766 as a Substrate of Biliary Efflux Transporters. E7766 was incubated with either MDR1-, BCRP-, BSEP-, or MRP2-expressing or control vesicle membranes. As shown in Fig. 2B, E7766 did not show transporter-mediated uptake activities in MDR1$(P>0.99)$, BCRP- $(P=0.17)$, and BSEP- $(P=0.45)$ expressing

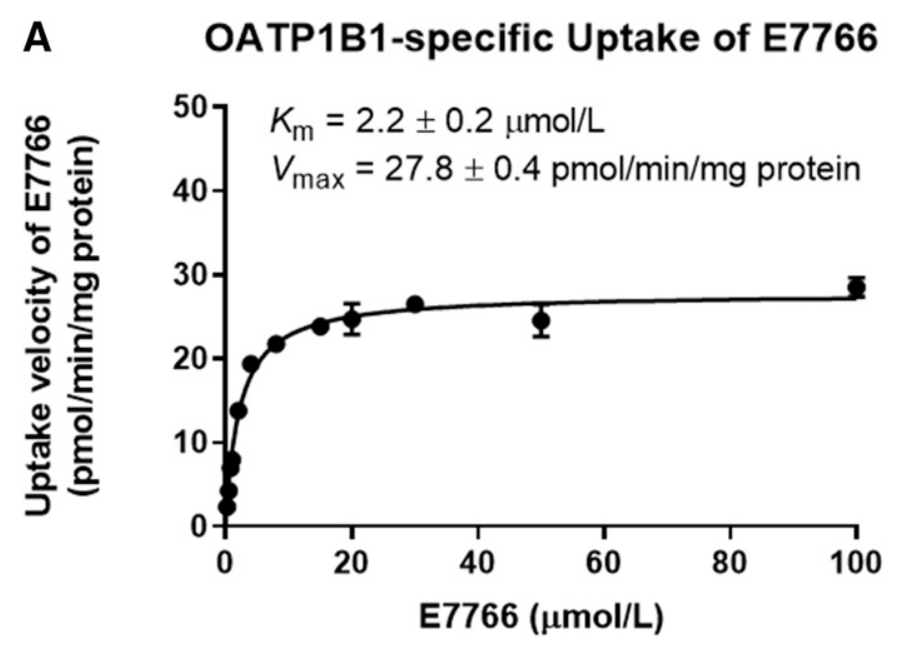

B

\section{OATP1B3-specific Uptake of E7766}

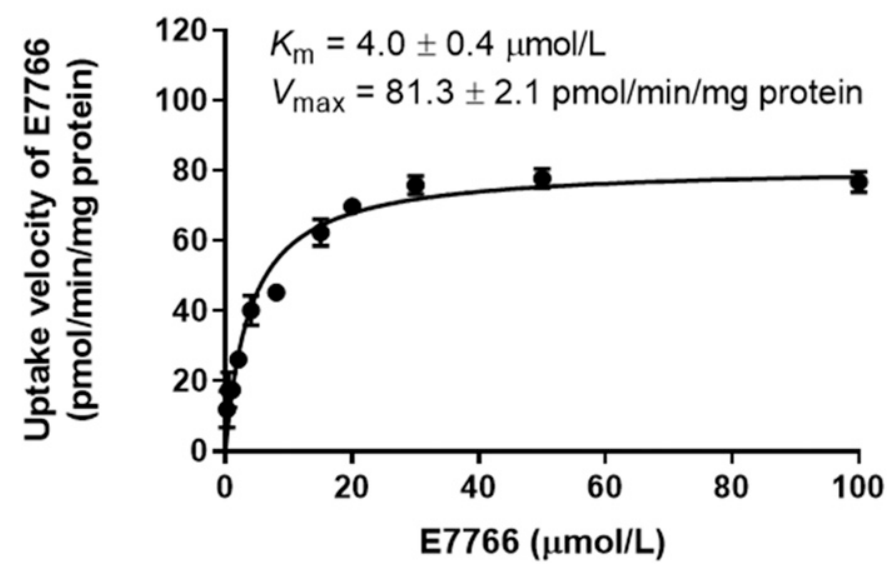

Fig. 3. In vitro transporter kinetics of E7766 were measured in HEK-293 cells expression OATP1B1 or OATP1B3. (A) Kinetics and Michaelis-Menten parameters of OATP1B1-mediated uptake of E7766. (B) Kinetics and Michaelis-Menten parameters of OATP1B3-mediated uptake of E7766. vesicles. Incubation of E7766 with MRP2-expressing vesicles resulted in greater uptake activity than that with control vesicles with an uptake ratio of 23 and a $P$ value of 0.00014 . Coincubation of E7766 and positive control inhibitor MK-571 (100 $\mu \mathrm{mol} / \mathrm{l})$ with MRP2-expressing vesicles decreased the uptake ratio from 23 to $1.1(P=0.00014)$. The results indicate that E7766 is a substrate of efflux transporter MRP2 but not a substrate of MDR1, BCRP, or BSEP (Fig. 2B). The transporter activity of positive control substrates for MDR1, MRP2, BCRP, and BSEP is shown in Supplemental Fig. 1B. The transcellular permeability of E7766 was assessed in LLC-PK1 cells. The results, as shown in Supplemental Table 1, indicate that E7766 exhibited very low permeability in LLCPK1 cells (apparanet permeability $<1 \times 10^{-6} \mathrm{~cm} / \mathrm{s}$ ).

Evaluation of Hepatic Uptake and Biliary Excretion of E7766 in SCHH. The transporter-mediated hepatic uptake potential of E7766 was evaluated in $\mathrm{SCHH}$ prepared from one donor (JEL). The intrinsic hepatic uptake clearance of E7766 (uptake $\mathrm{CL}_{\text {int,T }}$ ) at $4^{\circ} \mathrm{C}$ was markedly decreased to $<7.6 \%$ of that at $37^{\circ} \mathrm{C}$ at two lower dose levels $(0.3$ and $1.0 \mu \mathrm{mol} / \mathrm{l})\left(\right.$ Table 1). The uptake $\mathrm{CL}_{\mathrm{int}, \mathrm{T}}$ of E7766 across all dose levels dropped rapidly from 1 to 5 minutes (Table 1). These results suggest hepatic uptake was rapidly achieving near maximal accumulation within 5 minutes. In addition, the uptake $\mathrm{CL}_{\mathrm{int}, \mathrm{T}}$ decreased dramatically at $10 \mu \mathrm{mol} / \mathrm{l}$ across all exposure periods compared with uptake $\mathrm{CL}_{\mathrm{int}, \mathrm{T}}$ measured at 0.1 and $3 \mu \mathrm{mol} / 1$, suggesting hepatic uptake was saturated at concentration of $>1.0 \mu \mathrm{mol} / \mathrm{l}$ (Table 1). Taken together, these results suggest that hepatic uptake of E7766 was primarily mediated by a relatively fast active uptake mechanism.

As shown in Table 1, after 20-minute exposure, the intrinsic biliary efflux clearance (efflux $\mathrm{CL}_{\mathrm{int}, \mathrm{T}}$ ) decreased dramatically at $10 \mu \mathrm{mol} / \mathrm{l}$ compared with those at doses of 0.3 and $1 \mu \mathrm{mol} / \mathrm{l}$, suggesting hepatobiliary transport of E7766 was saturated at concentration of $>1.0 \mu \mathrm{mol} / \mathrm{l}$. The BEI of E7766 ranged from $70.9 \%$ to $86.2 \%$ across the concentration range assessed. These BEI values were comparable with d8-TCA (72.6\%), a model bile acid, and were $\sim 2$-fold greater than the reference compound Rosuvastatin $(\mathrm{BEI}=42.7 \%)$. The differences in BEI for Rosuvastatin and d8-TCA/E7766 are likely due to differences in uptake and efflux mechanisms as well as kinetics of uptake and efflux of these compounds in the SCHH system. Overall, these results suggest the biliary excretion of E7766 is mediated by a saturable mechanism and with a relatively high $\mathrm{BEI}$ value.

Pharmacokinetics of E7766 in BDC Rats and Dogs. The PK of E7766 in BDC rats (Table 2) was characterized by high total plasma clearance $\left(\mathrm{CL}_{\mathrm{tot}, \mathrm{p}}\right)(6.50 \mathrm{l} / \mathrm{h}$ per kilogram$)$ and moderate $V_{\mathrm{ss}}(2.47 \mathrm{l} / \mathrm{kg})$. The mean $\mathrm{Xu}_{(0-\mathrm{t})}$ and $\mathrm{Xb}_{(0-\mathrm{t})}$ up to 24 hours postdose were 38,600 and $261,000 \mathrm{ng}$, respectively, which corresponds to $13.7 \%\left(\mathrm{~A}_{\mathrm{e}}\right.$ renal $)$ and $92.1 \%\left(\mathrm{~A}_{\mathrm{e}}\right.$ biliary $)$ of the total dose administered, respectively. The mean cumulative amount of E7766 excreted in feces $\left(\mathrm{Xf}_{(0-\mathrm{t})}\right)$ up to 24 hours postdose was $991 \mathrm{ng}$, which corresponds to $0.4 \%$ of the total dose administered $\left(\mathrm{A}_{\mathrm{e}}\right.$ fecal $)$. Mean $\mathrm{CL}_{\text {renal }}, \mathrm{CL}_{\text {biliary }}$, and $\mathrm{CL}_{\text {fecal }}$ of E7766 in $\mathrm{BDC}$ rats were $0.895,6.04$, and $0.0227 \mathrm{l} / \mathrm{h}$ per kilogram, respectively.

The PK of E7766 in BDC dogs (Table 2) was characterized by moderate $\mathrm{CL}_{\text {tot,p }}(1.29 \mathrm{l} / \mathrm{h}$ per kilogram) and limited volume of distribution $\left(V_{\mathrm{ss}}, 0.553 \mathrm{l} / \mathrm{kg}\right)$. The mean cumulative amounts of unchanged E7766 excreted in urine $\left(\mathrm{Xu}_{(0-\mathrm{t})}\right)$ and bile $\left(\mathrm{Xb}_{(0-\mathrm{t})}\right)$ up to 48 hours postdose were 33,400 and $625,000 \mathrm{ng}$, respectively, which correspond to $5.0 \%\left(\mathrm{~A}_{\mathrm{e} \text { renal }}\right)$ and $87.9 \%\left(\mathrm{~A}_{\mathrm{e} \text { biliary }}\right)$ of the total dose administered, respectively. Mean renal $\left(\mathrm{CL}_{\text {renal }}\right)$ and biliary $\left(\mathrm{CL}_{\text {biliary }}\right)$ clearances of E7766 in dogs were 0.0528 and $1.19 \mathrm{l} / \mathrm{h}$ per kilogram, respectively.

Pharmacokinetics of E7766 in OATP1B1/1B3 Humanized and WT Mice. The plasma and liver PK of E7766 in WT mice was assessed with or without coadministration of Rifampicin (Fig. 4). The unbound concentration-time profiles of Rifampin in wild-type and humanized 
TABLE 1

Summary of in vitro parameters for E7766 estimated from the sandwich-cultured human hepatocytes

\begin{tabular}{|c|c|c|c|c|c|c|}
\hline Test Article & Target Conc. $(\mu \mathrm{mol} / \mathrm{l})$ & Temperature & Time (min) & $\begin{array}{c}\text { Uptake } \mathrm{CL}_{\text {int, } \mathrm{T}}(\mu \mathrm{l} / \mathrm{min} \text { per } \\
\left.10^{6} \text { cells }\right)\end{array}$ & $\begin{array}{c}\text { Efflux } \mathrm{CL}_{\text {int, } \mathrm{T}}(\mu \mathrm{l} / \mathrm{min} \text { per } \\
\left.10^{6} \text { cells }\right)\end{array}$ & BEI \% \\
\hline \multirow[t]{15}{*}{ E7766 } & 0.3 & $37^{\circ} \mathrm{C}$ & 1 & $7.69 \pm 0.47$ & - & - \\
\hline & & & 5 & $3.83 \pm 0.26$ & - & - \\
\hline & & & 10 & $3.12 \pm 0.26$ & - & - \\
\hline & & & 20 & Not determined & $2.05 \pm 0.07$ & $85.2 \pm 1.7$ \\
\hline & & $4^{\circ} \mathrm{C}$ & 10 & $0.13 \pm 0.00$ & - & - \\
\hline & 1.0 & $37^{\circ} \mathrm{C}$ & 1 & $5.46 \pm 0.10$ & - & - \\
\hline & & & 5 & $2.70 \pm 0.14$ & - & - \\
\hline & & & 10 & $1.85 \pm 0.13$ & - & - \\
\hline & & & 20 & Not determined & $1.42 \pm 0.08$ & $86.2 \pm 0.40$ \\
\hline & & $4^{\circ} \mathrm{C}$ & 10 & $0.14 \pm 0.02$ & - & - \\
\hline & 10.0 & $37^{\circ} \mathrm{C}$ & 1 & $1.22 \pm 0.11$ & - & - \\
\hline & & & 5 & $0.47 \pm 0.02$ & - & - \\
\hline & & & 10 & $0.33 \pm 0.01$ & - & - \\
\hline & & & 20 & Not determined & $0.15 \pm 0.01$ & $70.9 \pm 1.3$ \\
\hline & & $4^{\circ} \mathrm{C}$ & 10 & $0.58 \pm 0.73$ & - & - \\
\hline \multirow[t]{2}{*}{ d8-TCA } & 5 & $37^{\circ} \mathrm{C}$ & 10 & $14.2 \pm 0.82$ & $11.0 \pm 1.74$ & $72.6 \pm 5.8$ \\
\hline & & $4^{\circ} \mathrm{C}$ & & $0.27 \pm 0.02$ & - & - \\
\hline \multirow{2}{*}{ Rosuvastatin } & 10 & $37^{\circ} \mathrm{C}$ & 10 & $6.22 \pm 0.31$ & $2.23 \pm 0.38$ & $42.7 \pm 5.8$ \\
\hline & & $4^{\circ} \mathrm{C}$ & & $0.21 \pm 0.04$ & - & - \\
\hline
\end{tabular}

Efflux $\mathrm{CL}_{\mathrm{int}, \mathrm{T}}$, intrinsic biliary efflux clearance; uptake $\mathrm{CL}_{\mathrm{int}, \mathrm{T}}$, intrinsic hepatic uptake clearance. Values represent the mean $\pm \mathrm{S} . \mathrm{D}$. $(n=3)$.

mice are shown in Supplemental Fig. 3. The plasma PK of E7766 in WT was characterized by high $\mathrm{CL}_{\text {tot,p }}(8.93 \mathrm{l} / \mathrm{h}$ per kilogram) and moderate $V_{\mathrm{ss}}(1.66 \mathrm{l} / \mathrm{kg})$ (Table 3$)$. In the presence of Rifampicin, the plasma exposure $\left(\mathrm{AUC}_{\text {total }}\right)$ of E7766 in WT mice increased 5.4-fold with a corresponding decrease in $\mathrm{CL}_{\text {tot,p }}$. The liver exposure to E7766 was comparable in WT mice with or without coadministration of Rifampicin, indicating that Rifampicin only affects the plasma exposure and that liver exposure is unchanged by Rifampicin. However, the liver-toplasma ratio $K_{\mathrm{p} \text {,total }}$ of E7766 in Rifampicin-treated animals decreased by $82 \%$, indicating a strong inhibition of Oatp-mediated hepatic uptake of E7766 in mice (Table 3). The dose-normalized plasma exposure $\left(\mathrm{AUC}_{\text {total }} / \mathrm{dose}\right)$ and $\mathrm{CL}_{\mathrm{tot}, \mathrm{p}}$ were compared between WT mice $\left(\mathrm{AUC}_{\text {total }} /\right.$ dose: $112 \mathrm{ng} / \mathrm{h}$ per milliliter ${ }^{-1} /[\mathrm{mg} / \mathrm{kg}]$ and $\mathrm{CL}_{\text {tot, }}$ : $8.93 \mathrm{l} / \mathrm{h}$ per kilogram $)$ and OATP1B1/1B3 humanized mice $\left(\mathrm{AUC}_{\text {total }} /\right.$ dose: $126 \mathrm{ng} / \mathrm{h}$ per milliliter ${ }^{-1} /[\mathrm{mg} / \mathrm{kg}]$ and $\mathrm{CL}_{\text {tot, }}: 9.201 / \mathrm{h}$ per kilogram). The dose-normalized AUC in humanized mice increased 4.8-fold after coadministration with Rifampicin, which aligned with the increase in AUC (5.4-fold) in WT mice. We also assessed the percentage of the E7766 dose excreted in the urine and feces in the above studies (Fig. 4). The dose excreted in the feces in both WT and OATP1B1/1B3-humanized mice decreased to a similar extent (3-fold lower in WT mice and 4.6-fold lower in humanized mice) in the presence of Rifampicin. This decrease is in line with the corresponding increase in systemic exposure to E7766 in the presence of Rifampicin.

TABLE 2

Disposition of E7766 in BDC rat and dog after intravenous bolus administration

\begin{tabular}{|c|c|c|}
\hline Dose & $\begin{array}{l}\text { BDC Rat Intravenous Bolus, } \\
1 \mathrm{mg} / \mathrm{kg}\end{array}$ & $\begin{array}{c}\text { Dog Intravenous Bolus, } \\
0.075 \mathrm{mg} / \mathrm{kg}\end{array}$ \\
\hline $\mathrm{CL}_{\text {tot,p }}(\mathrm{l} / \mathrm{h}$ per kilogram $)$ & $6.50 \pm 0.429$ & $1.29 \pm 0.369$ \\
\hline $\mathrm{V}_{\mathrm{ss}}(1 / \mathrm{kg})$ & $2.47 \pm 0.849$ & $0.553 \pm 0.345$ \\
\hline $\mathrm{A}_{\mathrm{e} \text { renal }}(\%)$ & $13.7 \pm 2.80$ & $4.96 \pm 4.37$ \\
\hline$C L_{\text {renal }}(1 / h$ per kilogram $)$ & $0.895 \pm 0.189$ & $0.0528 \pm 0.0293$ \\
\hline $\mathrm{A}_{\mathrm{e} \text { biliary }}(\%)$ & $92.1 \pm 7.26$ & $87.9 \pm 30.5$ \\
\hline $\mathrm{CL}_{\text {biliary }}(\mathrm{l} / \mathrm{h}$ per kilogram $)$ & $6.04 \pm 0.798$ & $1.19 \pm 0.637$ \\
\hline $\mathrm{A}_{\mathrm{e} \text { fecal }}(\%)$ & $0.366 \pm 0.208$ & - \\
\hline $\mathrm{CL}_{\text {fecal }}(1 / \mathrm{h}$ per kilogram $)$ & $0.0227 \pm 0.0138$ & - \\
\hline
\end{tabular}

Values represent the mean \pm S.D. ( $n=4$ for BDC rats and $n=3$ for dogs).
PBPK Modeling and DDI Simulation of E7766. The PBPK model was built for E7766 and all input parameters that were used for the PBPK model are summarized in Table 4. The predicted plasma PK and systemic clearance as well as AUC ratio of E7766 in the presence and absence of Rifampicin are presented in Fig. 5 and Table 5. In scenario 1 of the DDI simulation, active uptake clearances measured as $J_{\max } / K_{\mathrm{m}}$ in HEK293 cells were assigned to OATP1B1 and OATP1B3, and the passive sinusoidal and biliary efflux clearances were taken from the SCHH experiment. Based on the REF factor and the in vitro uptake kinetics, the $f_{\mathrm{t}}$ for OATP1B3 and OATP1B1 were predicted to be 0.97 and 0.02 , respectively, thus suggesting that OATP1B3 plays a predominant role in the hepatic uptake of E7766 (Fig. 5A). The contribution of passive sinusoidal diffusion clearance to the overall uptake CL of E7766 was negligible (1\%, Fig. 5A). This simulation showed that the plasma $\mathrm{AUC}_{\text {total }}$ increased by 2.77 -fold, whereas the $C_{\max }$ in the presence of Rifampicin was unchanged (Fig. 5B). The free liver intracellular $C_{\max }$ of E7766 in the presence of Rifampicin decreased by $31.1 \%$, and E7766 concentration further decreased to $72.6 \%$ at 1 hour after dosing because of impairment of OATP1B function. However, as shown in Fig. 5C after 1 hour, the liver intracellular concentration started to increase at later time points and therefore resulted in an unchanged liver intracellular $\mathrm{AUC}_{\text {free }}(69.06 \mathrm{nmol} / \mathrm{h}$ per liter, Table 5) in presence of Rifampicin compared with Rifampicin-free group (76.19 nmol/h per liter, Table 5). This increase of liver concentrations at later time points is due an increase in the systemic exposure of E7766 in the presence of Rifampicin. A sensitivity analysis was performed for the in vitro parameters with uncertainty. As shown in Figs. 5, D-F, the change in AUC ratio ranged from 1.0 to 2.6 when the REF or kinetic parameters for OATP1B3 were varied. The AUC ratio remained unchanged when the REF or kinetic parameters for OATP1B1 were varied, indicating that the DDI was not sensitive to changes in $J_{\max }, K_{\mathrm{m}}$, and REF for OATP1B1. It is noteworthy that AUC ratio first increased along with the increase of OATP1B3 REF (when OATP1B3 REF < 3) and then started to drop as OATP1B3 REF increased further until AUC ratio became ultimately close to unity (Fig. 5D). One potential reason for this pattern is maybe that the hepatic uptake clearance increases when the OATP1B3 REF increases and will result in a larger DDI magnitude, (i.e., a greater AUC ratio in the beginning when REF is in a relatively low range). However, as the OATP1B3 REF increases further (above 3), the intrinsic uptake 


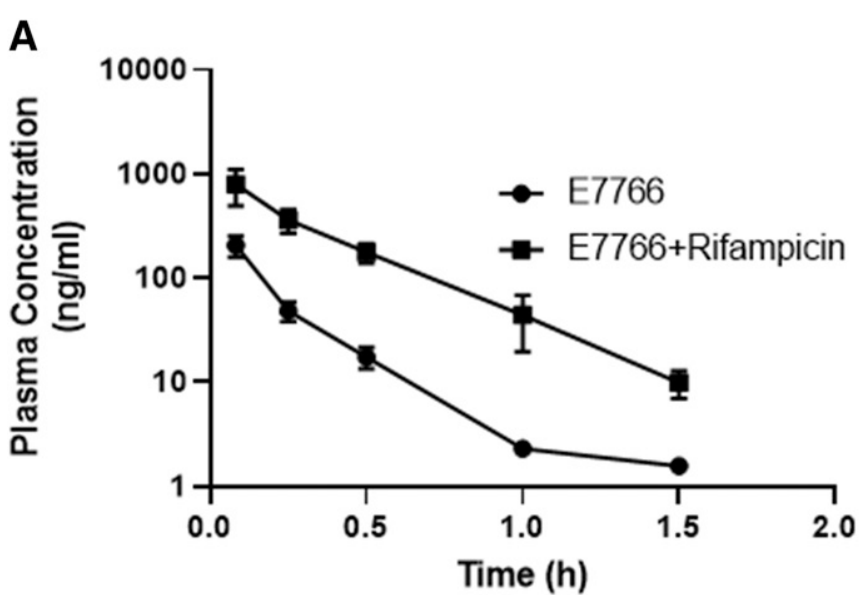

B

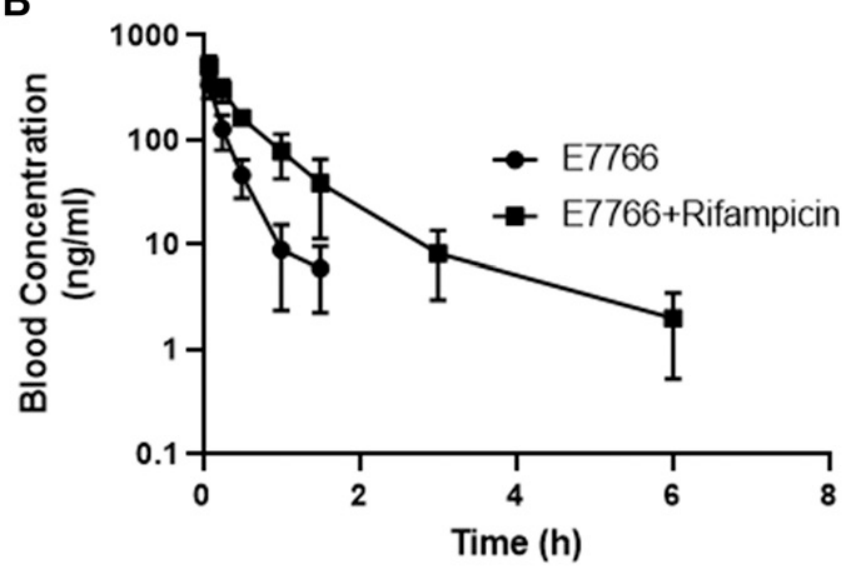

C

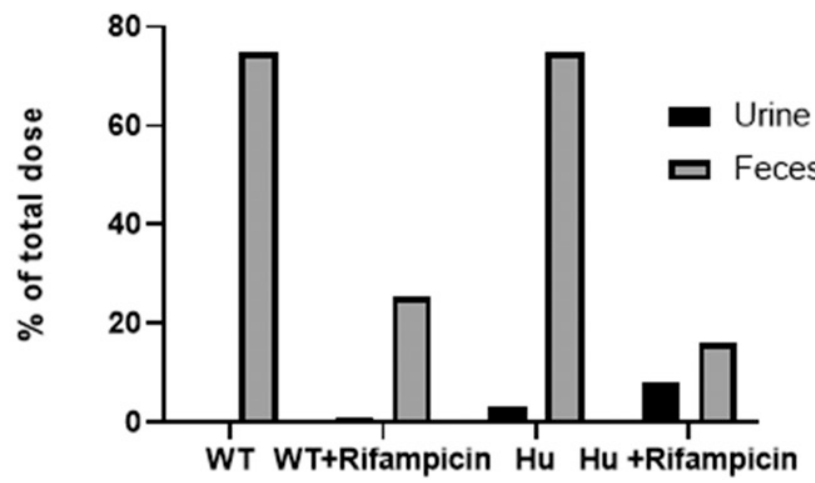

Fig. 4. Pharmacokinetics and disposition of E7766 after intravenous administration in wild-type and OATP1B1/1B3-humanized mice. (A) Plasma concentrations of E7766 were measured with or without coadministration with Rifampicin after intravenous administration of E7766 and Rifampicin. (B) Blood concentrations of E7766 were measured with or without coadministration with Rifampicin after intravenous administration of E7766 and Rifampicin. (C) Excretion with or without coadministration with Rifampicin of E7766 in urine, bile, and feces was determined after intravenous administration of E7766 and Rifampicin. Hu, humanized mouse.

clearance will exceed hepatic blood flow and become a blood-flow ratelimited process. Therefore the AUC is not readily affected by inhibition of uptake clearance. We speculate that another explanation may be that E7766 is cleared away from the transporter binding site very rapidly when REF increases further. Thus there is not enough duration of exposure for E7766 (given as intravenous bolus dose) to have interaction with orally administered Rifampicin, which needs time to get to the interaction site in liver.
In the second scenario, DDI was simulated using active uptake, passive sinusoidal uptake, and biliary efflux clearances measured in SCHH experiment. In this simulation, we observed similar results for both PK profile and DDI potential of E7766 as victim compared with the first scenario. The comparison between two different scenarios is summarized in Table 5. Simulation showed that the plasma AUC increased by 2.59 -fold, whereas the $C_{\max }$ in the presence of Rifampicin was unchanged. The liver $\mathrm{AUC}_{\text {free }}$ calculated by free intracellular concentrations remained unchanged in the presence of Rifampicin with a liver $\mathrm{AUC}_{\text {free }}$ ratio of 0.86 . The consistency of prediction from two scenarios that adopted experimental data from two independent approaches suggests that the PBPK model is mechanistically sound.

\section{Discussion}

E7766 is a macrocycle-bridged dinucleotide under development as an immuno-oncology drug to be used as a single agent or in combination with other standard-of-care therapies. For several drugs, such as pravastatin, which are cleared primarily via biliary excretion, hepatic uptake is in fact the rate-limiting step (Nakai et al., 2001), and inhibition of these uptake processes or polymorphisms in the hepatic uptake transporters may lead to clinically relevant change in the PK of drugs (Chen et al., 2018). Therefore, in vitro and in vivo studies were conducted for E7766 to systemically investigate drug transporters involved in its systemic clearance and to predict clinical DDI potential using PBPK models.

PK and excretion studies of E7766 were first conducted using BDC rats and BDC dogs. The results confirmed that biliary excretion plays predominant role in systemic clearance of E7766. To further study the clearance mechanisms of E7766, DDI studies with Rifampicin were conducted with OATP1B1/1B3-humanized and WT mice. Coadministration with Rifampicin in OATP1B1/1B3-humanized mice as well as WT mice resulted in an approximately 5-fold decrease in plasma clearance of E7766. We also measured the liver exposure of E7766 with and without coadministration with Rifampicin in WT mice. Although liver AUC was comparable between mice with or without Rifampicin, the observed decrease in liver/plasma ratio (liver $K_{\mathrm{p}, \text { total }}$ ) in WT mice in the presence of Rifampicin is consistent with hepatic OATP-mediated uptake. Studies in bile-duct cannulated dogs and rats show that biliary excretion of unchanged drug is the major route of clearance in preclinical species. Fecal excretion of unchanged drug was also observed in humanized and WT animals, and excretion into the feces decreased substantially in animals wherein liver OATP/oatp function was

TABLE 3

Liver and systemic exposure of E7766 in wild-type and humanized mice in the presence or the absence of Rifampicin

\begin{tabular}{|c|c|c|c|c|}
\hline Parameters & $\begin{array}{c}\text { WT Mice } \\
0.5 \mathrm{mg} / \mathrm{kg} \\
\text { E7766 }\end{array}$ & $\begin{array}{c}\text { WT Mice } \\
0.5 \mathrm{mg} / \mathrm{kg} \\
\text { E7766 } \\
\text { +Rifampicin }\end{array}$ & $\begin{array}{c}\text { Hu Mice } \\
1.0 \mathrm{mg} / \mathrm{kg} \\
\text { E7766 }\end{array}$ & $\begin{array}{c}\text { Hu Mice } \\
0.5 \mathrm{mg} / \mathrm{kg} \\
\text { E7766 } \\
+ \text { Rifampicin }\end{array}$ \\
\hline $\operatorname{AUC}_{\text {total }}(\mathrm{ng} \bullet \mathrm{h} / \mathrm{ml})$ & 56.0 & 300 & $126 \pm 48.7$ & $302 \pm 92.2$ \\
\hline $\begin{array}{c}\mathrm{AUC}_{\text {total }} / \text { dose } \\
(\mathrm{ng} \bullet \mathrm{h} / \mathrm{ml} / \\
[\mathrm{mg} / \mathrm{kg}])\end{array}$ & 112 & 600 & $126 \pm 48.7$ & $604 \pm 184$ \\
\hline $\begin{array}{l}\mathrm{CL}_{\text {tot,p }}(\mathrm{l} / \mathrm{h} \text { per } \\
\text { kilogram })\end{array}$ & 8.93 & 1.72 & $9.20 \pm 4.65$ & $1.80 \pm 0.619$ \\
\hline$V_{\mathrm{ss}}(1 / \mathrm{kg})$ & 1.66 & 0.520 & $5.93 \pm 5.96$ & $1.29 \pm 0.243$ \\
\hline $\begin{array}{l}\text { Liver AUC } \text { total } \\
(\mathrm{ng} \cdot \mathrm{h} / \mathrm{g})\end{array}$ & 4460 & 4250 & - & - \\
\hline Liver $K_{\mathrm{p} \text {,total }}$ & 79.6 & 14.2 & - & - \\
\hline
\end{tabular}

$\mathrm{AUC}_{\text {total }} / \mathrm{dose}$, area under the total plasma conc.-time curve normalized by dose; $\mathrm{Hu}$, OATP1B1/OATP1B3-humanized mouse; liver $\mathrm{AUC}_{\text {total }}$, area under the total liver conc.-time curve. Values represent the mean \pm S.D. $(n=3)$. 
TABLE 4

Summary of input parameters used to build the PBPK model for E7766

\begin{tabular}{|c|c|c|c|}
\hline Parameter & Scenario 1 & Scenario 2 & Source \\
\hline \multicolumn{4}{|l|}{ PhysChem and blood binding } \\
\hline Mol. wt. (g/mol) & 746 & 746 & Calculated \\
\hline $\log \mathrm{P}$ & 1.31 & 1.31 & Measured \\
\hline Compound type & $\begin{array}{l}\text { Monoprotic } \\
\quad \text { acid }\end{array}$ & $\begin{array}{l}\text { Monoprotic } \\
\quad \text { acid }\end{array}$ & - \\
\hline $\mathrm{pKa}$ & 3.41 & 3.41 & Calculated \\
\hline $\mathrm{B} / \mathrm{P}$ & 0.55 & 0.55 & Measured \\
\hline$f_{\mathrm{u}}$ & 0.50 & 0.50 & Measured \\
\hline Distribution model & $\begin{array}{l}\text { Full PBPK } \\
\text { model }\end{array}$ & $\begin{array}{l}\text { Full PBPK } \\
\text { model }\end{array}$ & - \\
\hline $\mathrm{V}_{\mathrm{ss}}(1 / \mathrm{kg})$ & 0.637 & 0.637 & SimCYP predicted (method 2, the Rodgers-Rowland method) \\
\hline$K_{\mathrm{p}}$ scalar & 4.0 & 4.0 & Fitted based on preclinical data, see Materials and Methods for details \\
\hline $\mathrm{CL}_{\text {renal }}(1 / \mathrm{h})$ & 3.0 & 3.0 & Estimate as $f_{\mathrm{u}} \times$ glomerular filtration rate \\
\hline \multicolumn{4}{|c|}{ Hepatic transport (permeability-limited liver module) } \\
\hline $\begin{array}{l}\text { Passive diffusion } \mathrm{CL}_{\mathrm{PD}}(\mathrm{ml} / \\
\left.\text { min per } 10^{6} \text { cells }\right)\end{array}$ & 0.00013 & 0.00013 & Obtained from E7766 uptake measured at $0.3 \mu \mathrm{mol} / 1$ at $4{ }^{\circ} \mathrm{C}$ with SCHH model (Table 1) \\
\hline fuIW & 1.00 & 1.00 & SimCYP predicted \\
\hline fuEW & 0.657 & 0.657 & SimCYP predicted \\
\hline $\begin{array}{l}J_{\max }\left(\mathrm{pmol} / \mathrm{min} \text { per } 10^{6} \text { cells }\right) \\
\text { for OATP1B1 }\end{array}$ & 8.34 & - & $\begin{array}{l}\left.V_{\max } \text { in the unit of pmol/min } / \mathrm{mg} \text { protein (Fig. } 3\right) \text { was converted to } J_{\max } \text { in the unit picomoles per } \\
\text { minute per } 10^{6} \text { cells by incorporating measured protein abundance data of HEK293 cells }(0.3 \mathrm{mg} \\
\text { protein per } 10^{6} \text { HEK293 cells) }\end{array}$ \\
\hline$K_{\mathrm{m}}(\mu \mathrm{mol} / \mathrm{l})$ for OATP1B1 & 2.20 & - & Obtained from transporter kinetic assays (Fig. 3) \\
\hline$f_{\text {uinc }}$ for OATP1B1 & 1.00 & - & SimCYP predicted \\
\hline REF for OATP1B1 & 0.10 & - & Calculated by eq. 4 , see Supplemental Table 2 for details of transporter protein expression. \\
\hline $\begin{array}{l}J_{\max }\left(\mathrm{pmol} / \mathrm{min} \text { per } 10^{6} \text { cells }\right) \\
\text { for OATP1B3 }\end{array}$ & 24.39 & - & Fig. 3. Units were converted as shown above for OATP1B1 \\
\hline$K_{\mathrm{m}}(\mu \mathrm{mol} / \mathrm{l})$ for OATP1B3 & 3.97 & - & Obtained from transporter kinetic assays (Fig. 3) \\
\hline$f_{\text {uinc }}$ for OATP1B3 & 1.00 & 1.00 & SimCYP predicted \\
\hline REF for OATP1B3 & 2.80 & - & Calculated by eq. 5 , see Supplemental Table 2 for details of transporter protein expression. \\
\hline $\begin{array}{l}\text { Uptake } \mathrm{CL}_{\text {int }, \mathrm{T}}(\mu \mathrm{l} / \mathrm{min} \text { per } \\
\left.10^{6} \text { cells }\right)\end{array}$ & - & 7.7 & $\begin{array}{l}\text { For scenario 2, the uptake } \mathrm{CL}_{\text {int, } \mathrm{T}} \text { for E7766 measured at } 0.3 \mu \mathrm{mol} / 1 \text { after } 1 \text { min incubation at } 37^{\circ} \mathrm{C} \\
\text { (Table 1) was assigned as input value for uptake } \mathrm{CL}_{\text {int, } \mathrm{T}} \text { in } \mathrm{SCHH} \text {, as early time point and lower } \\
\text { conc. can better represent the initial linear uptake phase. }\end{array}$ \\
\hline $\mathrm{REF}_{\mathrm{SCHH}}$ & - & 1 & $\begin{array}{l}\text { The } \mathrm{REF}_{\mathrm{SCHH}} \text { is assumed to be one based on literature reported data shown that OATP1B1 and } \\
\text { OATP1B3 expression levels are comparable between SCHH and primary hepatocyte if from the } \\
\text { same lot (Kimoto, 2012) }\end{array}$ \\
\hline $\begin{array}{l}\text { Efflux } \mathrm{CL}_{\mathrm{int}, \mathrm{T}}\left(\mu \mathrm{l} / \mathrm{min} \text { per } 10^{6}\right. \\
\text { cells) }\end{array}$ & 2.1 & 2.1 & $\begin{array}{l}\text { For both scenarios } 1 \text { and } 2, \mathrm{SCHH} \text { efflux } \mathrm{CL}_{\text {int,T }} \text { for E7766 measured at } 0.3 \mu \mathrm{mol} / 1 \text { after } 20 \text {-min } \\
\text { incubation at } 37^{\circ} \mathrm{C} \text { (Table 1) was used as input value for efflux } \mathrm{CL}_{\mathrm{int}, \mathrm{T}} \text {. }\end{array}$ \\
\hline
\end{tabular}

$\mathrm{B} / \mathrm{P}$, blood-to-plasma partition ratio; $\mathrm{CL}_{\mathrm{PD}}$, passive diffusion clearance; $f_{\mathrm{u}}$, unbound drug fraction in plasma; fuIW, unbound drug fraction in intracellular water; fuEW, unbound drug fraction in

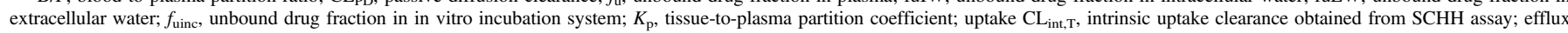

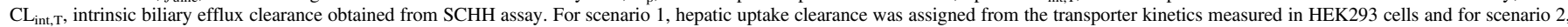
intrinsic active uptake clearance measured in from SCHH was assigned to OATP1B3.

inhibited. Taken together, these results suggest that E7766 is cleared from systemic circulation primarily via active uptake into the liver by OATP/oatp and then excreted unchanged into the bile. Previous reports have shown that hepatic expression of OATP1B1 in the humanized mice was lower than that in human liver, whereas the expression of OATP1B3 was 3-fold higher than that in human liver (Higgins et al., 2014). These differences in the expression could lead to the overestimation of the contribution of OATP1B3 on the systemic exposure of OATP substrates in humanized mice. However, OATP1B1/1B3-humanized mice may still be useful in qualitatively determining whether hepatic OATP can impact systemic exposure and hepatic distribution of substrates.

To prospectively predict clinical DDI potential for E7766 as the victim drug, we used in vitro kinetic data generated from transporteroverexpressing cell lines coupled with REF approach (scenario 1) and $\mathrm{CL}_{\text {int }}$ data from SCHH coupled with REF approach (scenario 2) to build "bottom-up" full PBPK models and run DDI simulations. DDI simulation with Rifampicin suggests that Rifampicin may cause about 2-3-fold increase in plasma AUC in both scenarios, indicating that the current PBPK model is mechanistically sound. Similar to the findings in mice treated with Rifampicin, PBPK simulation showed that the intracellular free liver AUC did not change with treatment with Rifampicin; however, the liver-to-plasma ratio decreased in the presence of Rifampicin. Previously reported PBPK approaches suggested the need for empirical scaling factors for hepatic active uptake to recover human PK of several OATP substrates (Watanabe, et al., 2009; Jones et al., 2012). These scaling factors are derived from "top down" approaches and are often compound-specific (Varma et al., 2013). Hence the model developed here will need to be verified, and E7766specific scaling factors will be derived once clinical PK and DDI data for E7766 are available.

For prospective DDI assessment, a sensitivity analysis of parameters that have high uncertainty is important. For transporter-mediated DDIs, there is significant uncertainty due to the limited understanding of quantitative translation of in vitro transporter kinetics to the clinical scenario. Hence we conducted a sensitivity analysis of the in vitro $J_{\max }$, $K_{\mathrm{m}}$, and REF values. The sensitivity analysis results show that AUC ratio was less sensitive to changes in the kinetic parameters for OATP1B1 than those of OATP1B3 because of predominant role of OATP1B3 in the overall clearance. On the other hand, based on $f_{\mathrm{t}}$ of E7766 for OATP1B1 and the sensitivity analysis, we can conclude that the pharmacokinetics of E7766 is less likely to be influenced by polymorphisms in OATP1B1. Although the impact of genetic polymorphisms of OATP1B1 on the PK/pharmacodynamics of OATP1B substrates has been well documented (Niemi et al., 2011), that of OATP1B3 polymorphisms has not been clearly reported. Reduced uptake of glibenclimide and glipizide by OATP1B3 in HEK cells expressing OATP1B3 (699 G > A) was recently reported (Yang et al., 
A

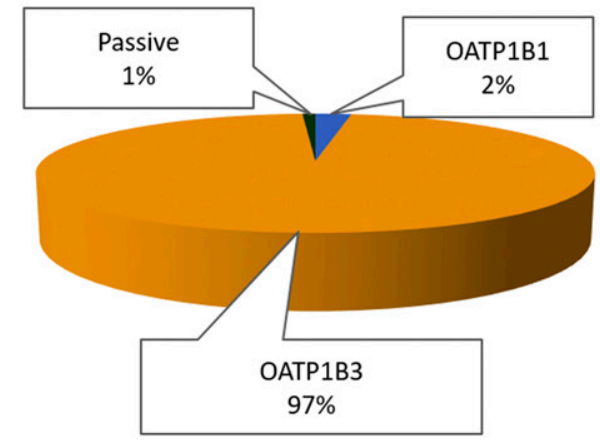

C

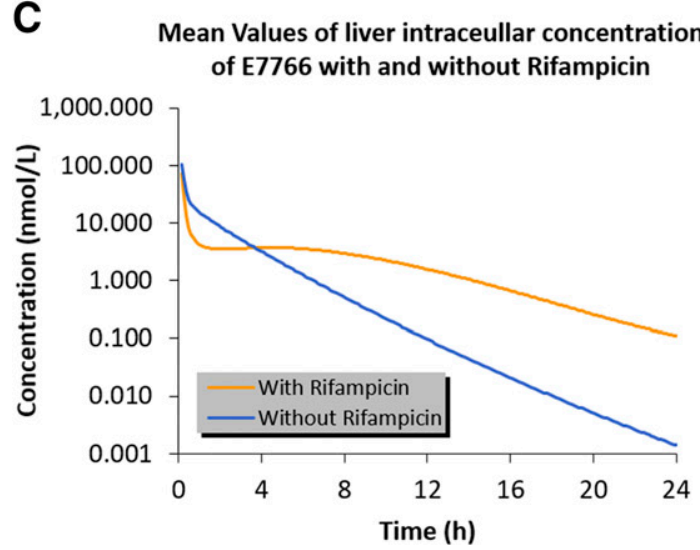

$\mathbf{E}$

Sensitivity analysis of OATP1B1 kinetic parameters

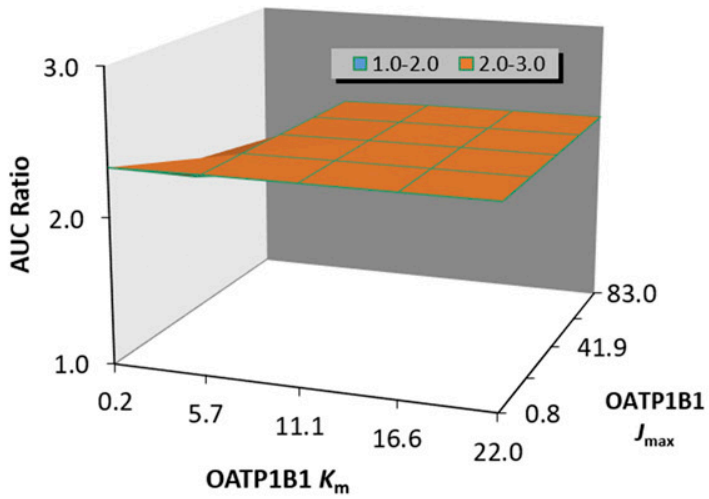

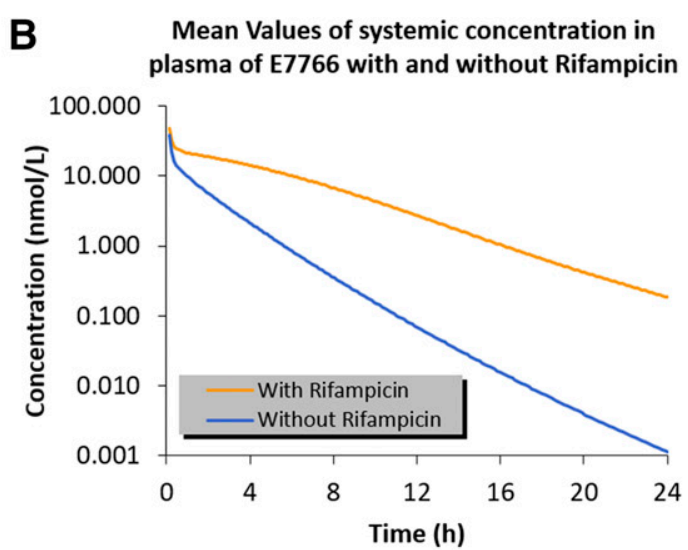

D

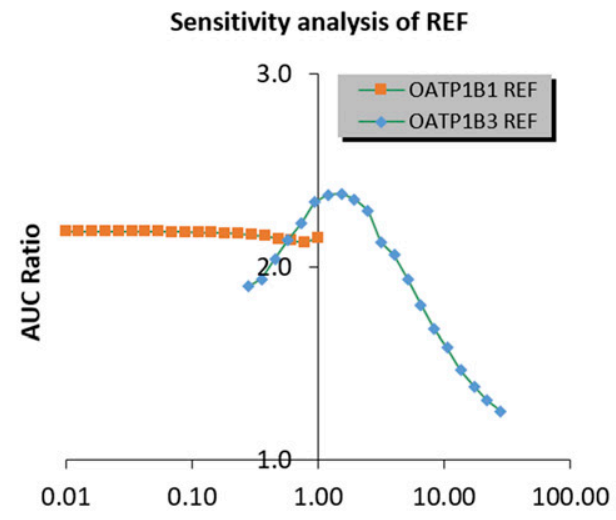

$\mathbf{F}$

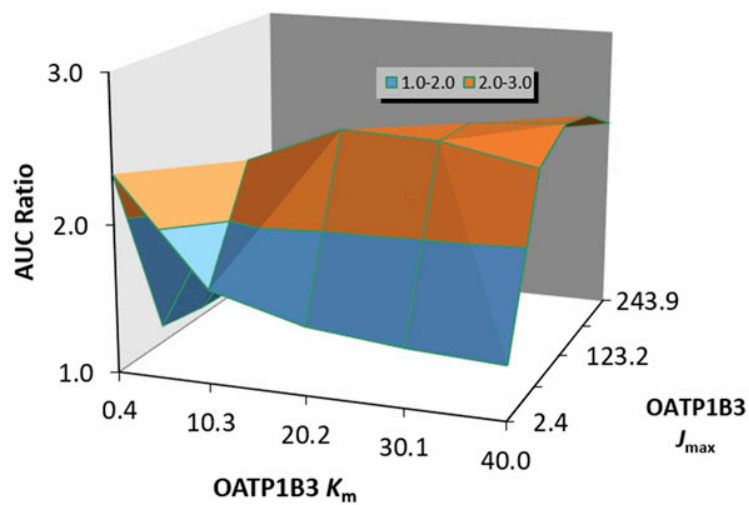

Fig. 5. Summary of PK parameters and DDI profile of E7766 from PBPK model. (A) Contribution of passive diffusion and OATP1B1- and OATP1B3-mediated uptake to overall hepatic uptake clearance of E7766. Simulated plasma (B) and liver (C) concentration-time profiles of E7766 after intravenous administration of 1-mg dose with and without 600-mg oral dose of Rifampicin. Sensitivity analysis of changes in E7766 area under the curve ratio as a function of REF (D) and kinetic parameters for OATP1B1 (E) and OATP1B3 (F).

2018). However, there are no reported clinical studies to support these in vitro observations. It is, however, advisable to genotype patients and healthy volunteers for any potential OATP1B3 polymorphisms to understand any interindividual variability in E7766 exposure.

E7766 was also identified as a novel substrate of MRP2, an efflux transporter expressed on the canalicular membrane of human hepatocytes. MRP2 is essential for hepatobiliary and renal elimination of many anionic substrates, including drugs and conjugates, such as bilirubin glucuronides (Nies and Keppler, 2007). It was reported that Rifampicin when dosed $600 \mathrm{mg}$ orally may inhibit MRP2-mediated biliary excretion of ${ }^{11} \mathrm{C}$-labeled (15R)-16-m-tolyl-17,18,19,20-tetranorisocarbacyclin methyl ester (Takashima et al., 2012). However, it is likely that the OATP-mediated uptake rather than MRP2-mediated efflux influences the systemic exposure of E7766. This conclusion is based on 1) ECCS classification, which states that hepatic uptake will be the major contributor to the clearance of class $3 \mathrm{~B}$ compounds, and 2) other reports (Watanabe, et al., 2009) that the impairment of MRP2 would only affect the liver AUC but would have no impact on plasma AUC if the compound were uptake-limited. To the best of our knowledge, no systemic DDI has been attributed to MRP2, and there is no evidence that 
TABLE 5

Summary and comparison of simulated PK and DDI parameters of E7766 from PBPK models using two scenarios

SimCYP default compound for Rifampicin was used for simulations. For scenario 1, hepatic uptake clearance was assigned from the transporter kinetics measured in HEK293 cells, and for scenario 2, intrinsic active uptake clearance measured in from SCHH was assigned to OATP1B3.

\begin{tabular}{|c|c|c|c|c|}
\hline \multirow[b]{2}{*}{ PK Profile Parameters of E7766 } & \multicolumn{2}{|c|}{ Scenario 1} & \multicolumn{2}{|c|}{ Scenario 2} \\
\hline & $\begin{array}{c}(-) \\
\text { Rifampicin }\end{array}$ & $\begin{array}{c}(+) \\
\text { Rifampicin }\end{array}$ & $\begin{array}{c}(-) \\
\text { Rifampicin }\end{array}$ & $\begin{array}{c}(+) \\
\text { Rifampicin }\end{array}$ \\
\hline $\mathrm{AUC}_{\text {total }}(\mathrm{nmol} \cdot \mathrm{h} / \mathrm{l})$ & 47.38 & 131.06 & 67.26 & 174.07 \\
\hline $\mathrm{AUC}_{\text {total }}$ ratio & 2.77 & & 2.59 & \\
\hline$C_{\max , \text { tot }}(\mathrm{nmol} / \mathrm{l})$ & 474.01 & 479.92 & 476.24 & 480.12 \\
\hline$C_{\max , \text { tot }}$ ratio & 1.01 & & 1.01 & \\
\hline $\mathrm{CL}_{\text {tot,p }}(\mathrm{l} / \mathrm{h})$ & 29.62 & 11.88 & 21.55 & 8.66 \\
\hline $\mathrm{CL}_{\text {tot,p }}$ ratio & 0.40 & & 0.40 & \\
\hline $\begin{array}{l}\text { Liver intracellular } \mathrm{AUC}_{\text {free }} \\
(\mathrm{nmol} \cdot \mathrm{h} / \mathrm{l})\end{array}$ & 76.19 & 69.06 & 71.35 & 61.28 \\
\hline $\begin{array}{l}\text { Liver intracellular } \mathrm{AUC}_{\text {free }} \\
\text { ratio }\end{array}$ & 0.91 & & 0.86 & \\
\hline
\end{tabular}

$\mathrm{AUC}_{\text {total }}$ ratio, ratio of $\mathrm{AUC}_{\text {total }}$ in the presence and absence of the inhibitor; $\mathrm{CL}_{\text {tot } \mathrm{p}}$ ratio, ratio of $\mathrm{CL}_{\text {tot,p }}$ in the presence and absence of the inhibitor; $C_{\text {max tot }}$, maximum total plasma conc.; $C_{\text {max,tot }}$ ratio, ratio of $C_{\text {max,tot }}$ in the presence and absence of the inhibitor; liver intracellular $\mathrm{AUC}_{\text {free }}$ ratio, ratio of area under free intrahepatocellular conc.-time curve in the presence and absence of the inhibitor.

MRP3 or MRP4 should be examined or that there is a likelihood of DDI for a substrate of MRP2 (Hillgren et al., 2013).

Further studies are warranted to investigate whether other dinucleotide NCEs are also substrates of OATP1Bs and MRP2. A recent paper published by Luteijn and coworkers (2019) identified solute carrier (SLC) 19A1 (folate-organic phosphate antiporter) as the major transporter to facilitate cellular uptake of cyclic dinucleotides, such as $2^{\prime} 3^{\prime}$ cyclic guanosine monophosphate-adenosine monophosphate, into THP-1 cells and therefore has implications for the immunotherapeutic treatment of cancer. The uptake of $2^{\prime} 3^{\prime}$-cyclic guanosine monophosphate-adenosine monophosphate was inhibited by methotrexate and sulfasalazine, inhibitors of SLC transporters. OATP1B1, OATP1B3, and other OATP transporters are also found in multiple cancer cells, including breast cancer, colon cancer, liver cancer, pancreatic cancer, prostate cancer, testicular cancer, and thyroid cancer (Wlcek et al., 2008; Pressler et al., 2011). Given that cellular permeability of E7766 or its analogs could be low because of their physiochemical properties, additional investigation into whether other analogs of E7766 are substrates of OATP1B1/1B3, SLC19A1, or other OATP transporters expressed in hepatocytes, immune cells, or cancer cells can provide insight into absorption, distribution, metabolism, and excretion properties and pharmacological function of these novel NCEs.

In summary, our data show that transporter-mediated hepatic uptake is the major contributor to the overall systemic clearance of E7766. Based on the estimated $f_{\mathrm{t}}$ for OATP1B3 and OATP1B1, we conclude that OATP1B3 plays a predominant role in the hepatic uptake of E7766. The findings reported here have a significant influence on the design of clinical pharmacology program for E7766. Because of near-complete recovery of unchanged E7766 observed in preclinical animal studies, the clinical protocols emphasized the need for collecting urine and fecal samples from patient volunteers in phase I studies to measure the recovery of E7766 in early clinical studies, which will give us useful information about renal and biliary clearances of E7766 in humans. This information could help with the design of an appropriate human absorption, distribution, metabolism, and excretion study and accelerate clinical development of E7766. Since nonclinical studies have identified transporters responsible for clearance of E7766, appropriate clinical DDI studies can be designed, and the PBPK model developed here can be used to predict DDI with perpetrators or coadministered therapies.
Finally, the results collected from current studies may also shed light on pharmacokinetics and pharmacodynamics of other compounds from this class of macrocycle-bridged dinucleotides.

\section{Acknowledgments}

The authors would like to thank Kazutomi Kusano, Takafumi Komori, Yoshitane Nozaki, Naomi Wakayama, Saki Izumi, and Raku Shinkyo from Eisai Co. LTD., Tsukuba, Japan for review and helpful scientific discussions during the preparation of this manuscript.

\section{Authorship Contributions}

Participated in research design: Jiang, Hart, Lai, Dixit.

Conducted experiments: Jiang, Hart, Burgess.

Contributed new reagents or analytic tools: Kim.

Performed data analysis: Jiang, Hart, Dixit.

Wrote or contributed to the writing of the manuscript: Jiang, Dixit.

\section{References}

Chen Y, Zhu R, Ma F, Mao J, Chen EC, Choo EF, Sahasranaman S, and Liu L (2018) Assessment of OATP transporter-mediated drug-drug interaction using physiologically-based pharmacokinetic (PBPK) modeling - a case example. Biopharm Drug Dispos 39:420-430.

Corrales L, McWhirter SM, Dubensky TW Jr, and Gajewski TF (2016) The host STING pathway at the interface of cancer and immunity. J Clin Invest 126:2404-2411.

Duan P, Zhao P, and Zhang L (2017) Physiologically based pharmacokinetic (PBPK) modeling of pitavastatin and atorvastatin to predict drug-drug interactions (DDIs). Eur J Drug Metab Pharmacokinet 42:689-705.

Endo Atsushi, Kim DS, Huang KC, Hao M, Mathieu S, Choi HW, Majumder U, Zhu X, Shen Y, Sanders K, et al. (2019) Discovery of E7766: A representative of a novel class of macrocycle-bridged STING agonists (MBSAs) with superior potency and pan-genotypic activity. Cancer Res 79:4456.

European Medicines Agency (2012) Guideline on the investigation of drug interactions, Committee for Human Medicinal Products (CHMP), London.

Higgins JW, Bao JQ, Ke AB, Manro JR, Fallon JK, Smith PC, and Zamek-Gliszczynski MJ (2014) Utility of Oatp1a/1b-knockout and OATP1B1/3-humanized mice in the study of OATPmediated pharmacokinetics and tissue distribution: case studies with pravastatin, atorvastatin, simvastatin, and carboxydichlorofluorescein. Drug Metab Dispos 42:182-192.

Hillgren KM, Keppler D, Zur AA, Giacomini KM, Stieger B, Cass CE, and Zhang L; International Transporter Consortium (2013) Emerging transporters of clinical importance: an update from the International Transporter Consortium. Clin Pharmacol Ther 94:52-63.

Hirano M, Maeda K, Shitara Y, and Sugiyama Y (2004) Contribution of OATP2 (OATP1B1) and OATP8 (OATP1B3) to the hepatic uptake of pitavastatin in humans. J Pharmacol Exp Ther 311: 139-146.

Huang KC, Endo A, McGrath S, Chandra D, Wu J, Kim DS, Albu D, Ingersoll C, Tendyke K, Loiacono K, et al. (2019) Discovery and characterization of E7766, a novel macrocycle-bridged STING agonist with pan-genotypic and potent antitumor activity through intravesical and intratumoral administration. Cancer Res 79:3269.

Jiang R, Dong J, Li X, Du F, Jia W, Xu F, Wang F, Yang J, Niu W, and Li C (2015) Molecular mechanisms governing different pharmacokinetics of ginsenosides and potential for ginsenosideperpetrated herb-drug interactions on OATP1B3. Br J Pharmacol 172:1059-1073.

Jones HM, Barton HA, Lai Y, Bi YA, Kimoto E, Kempshall S, Tate SC, El-Kattan A, Houston JB, Galetin A, et al. (2012) Mechanistic pharmacokinetic modeling for the prediction of transportermediated disposition in humans from sandwich culture human hepatocyte data. Drug Metab Dispos 40:1007-1017.

Jones HM, Chen Y, Gibson C, Heimbach T, Parrott N, Peters SA, Snoeys J, Upreti VV, Zheng M, and Hall SD (2015) Physiologically based pharmacokinetic modeling in drug discovery and development: a pharmaceutical industry perspective. Clin Pharmacol Ther 97:247-262.

Kimoto Emi, et al. (2012) Characterization of organic anion transporting polypeptide (OATP) expression and its functional contribution to the uptake of substrates in human hepatocytes. $\mathrm{Mol}$ Pharm 9:3535-3542.

Kunze A, Huwyler J, Camenisch G, and Poller B (2014) Prediction of organic anion-transporting polypeptide 1B1- and 1B3-mediated hepatic uptake of statins based on transporter protein expression and activity data. Drug Metab Dispos 42:1514-1521.

Lin J, Knight EL, Hogan ML, and Singh AK (2003) A comparison of prediction equations for estimating glomerular filtration rate in adults without kidney disease. J Am Soc Nephrol 14: 2573-2580.

Luteijn RD, Zaver SA, Gowen BG, Wyman SK, Garelis NE, Onia L, McWhirter SM, Katibah GE, Corn JE, Woodward JJ, et al. (2019) SLC19A1 transports immunoreactive cyclic dinucleotides. Nature 573:434-438.

Marloye M, Lawler SE, and Berger G (2019) Current patent and clinical status of stimulator of interferon genes (STING) agonists for cancer immunotherapy. Pharm Pat Anal 8:87-90.

Nakai D, Nakagomi R, Furuta Y, Tokui T, Abe T, Ikeda T, and Nishimura K (2001) Human liverspecific organic anion transporter, LST-1, mediates uptake of pravastatin by human hepatocytes. J Pharmacol Exp Ther 297:861-867.

Niemi M, Pasanen MK, and Neuvonen PJ (2011) Organic anion transporting polypeptide 1B1: a genetically polymorphic transporter of major importance for hepatic drug uptake. Pharmaco Rev 63:157-181.

Nies AT and Keppler D (2007) The apical conjugate efflux pump ABCC2 (MRP2). Pflugers Arch 453:643-659.

Pressler H, Sissung TM, Venzon D, Price DK, and Figg WD (2011) Expression of OATP family members in hormone-related cancers: potential markers of progression. PLoS One 6:e20372.

Rodgers T, Leahy D, and Rowland M (2005) Physiologically based pharmacokinetic modeling 1: predicting the tissue distribution of moderate-to-strong bases. J Pharm Sci 94:1259-1276. 
Rodgers T and Rowland M (2006) Physiologically based pharmacokinetic modelling 2: predicting the tissue distribution of acids, very weak bases, neutrals and zwitterions. J Pharm Sci 95:1238-1257. Schaefer O, Ohtsuki S, Kawakami H, et al. (2012) Absolute quantification and differential expression of drug transporters, cytochrome P450 enzymes, and UDP-glucuronosyltransferases in cultured primary human hepatocytes. Drug Metab Dispos 40:93-103.

Swift B, Pfeifer ND, and Brouwer KL (2010) Sandwich-cultured hepatocytes: an in vitro model to evaluate hepatobiliary transporter-based drug interactions and hepatotoxicity. Drug Metab Rev 42:446-471.

Takashima T, Kitamura S, Wada Y, Tanaka M, Shigihara Y, Ishii H, Ijuin R, Shiomi S, Nakae T, Watanabe Y, et al. (2012) PET imaging-based evaluation of hepatobiliary transport in humans with (15R)-11C-TIC-Me. J Nucl Med 53:741-748.

Tang YQ and Weng N (2013) Salting-out assisted liquid-liquid extraction for bioanalysis. Bioanalysis 5:1583-1598.

US Food and Drug Administration (2017) In vitro metabolism- and transporter-mediated drug-drug interaction studies: guidance for industry, Food and Drug Administration, Center for Drug Evaluation and Research (CDER), Silver Spring, MD.

Varma MV, Lai Y, Kimoto E, Goosen TC, El-Kattan AF, and Kumar V (2013) Mechanistic modeling to predict the transporter- and enzyme-mediated drug-drug interactions of repaglinide. Pharm Res 30:1188-1199.

Varma MV, Steyn SJ, Allerton C, and El-Kattan AF (2015) Predicting clearance mechanism in drug discovery: extended clearance classification system (ECCS). Pharm Res 32:3785-3802.

Wang Q, Zheng M, and Leil T (2017) Investigating transporter-mediated drug-drug interactions using a physiologically based pharmacokinetic model of rosuvastatin. CPT Pharmacometrics Syst Pharmacol 6:228-238.
Watanabe T, Kusuhara H, Maeda K, Shitara Y, and Sugiyama Y (2009) Physiologically based pharmacokinetic modeling to predict transporter-mediated clearance and distribution of pravastatin in humans. J Pharmacol Exp Ther 328:652-662.

Wlcek K, Svoboda M, Thalhammer T, Sellner F, Krupitza G, and Jaeger W (2008) Altered expression of organic anion transporter polypeptide (OATP) genes in human breast carcinoma. Cancer Biol Ther 7:1450-1455.

Woo SR, Fuertes MB, Corrales L, Spranger S, Furdyna MJ, Leung MY, Duggan R, Wang Y, Barber GN, Fitzgerald KA, et al. (2014) STING-dependent cytosolic DNA sensing mediates innate immune recognition of immunogenic tumors. Immunity 41:830-842.

Yang F, Liu L, Chen L, Liu M, Liu F, Xiong Y, Hu X, and Xia C (2018) OATP1B3 (699G>A) and $\mathrm{CYP} 2 \mathrm{C} 9 * 2, * 3$ significantly influenced the transport and metabolism of glibenclamide and glipizide. Sci Rep 8:18063.

Yoshikado T, Toshimoto K, Maeda K, Kusuhara H, Kimoto E, Rodrigues AD, Chiba K, and Sugiyama Y (2018) PBPK modeling of coproporphyrin I as an endogenous biomarker for drug interactions involving inhibition of hepatic OATP1B1 and OATP1B3. CPT Pharmacometrics Syst Pharmacol 7:739-747.

Address correspondence to: Dr. Rongrong Jiang, Drug Metabolism and Pharmacokinetics, Eisai Inc, Cambridge MA 02140. E-mail: Rongrong_jiang@ eisai.com; or Dr. Vaishali Dixit, Drug Metabolism and Pharmacokinetics, Eisai Inc, Cambridge, MA 02140. E-mail: dixitv77@gmail.com 